Atıf Bilgisi: Yaşar, İ. H. ve Uğurhan, Y. Z. C. (2021). Sosyal medyada güven ve teyit: Sosyal medya kullanım sıklığı bağlamında bir inceleme. INIF E-Dergi, 6(1), 32-52.

\title{
SOSYAL MEDYADA GÜVEN VE TEYITT: SOSYAL MEDYA KULLANIM SIKLIĞI BAĞLAMINDA BİR İNCELEME
}

\author{
Dr. Öğr. Üyesi İbrahim Halil YAŞAR* \\ Ögrr. Gör. Dr. Yusuf Zafer Can UĞURHAN** \\ DOI: 10.47107/inifedergi.856506
}

Araștırma Makalesi

Başvuru Tarihi: 08.01.2021

Kabul Tarihi: 13.04 .2021

\begin{abstract}
Öz
Sosyal medya küresel anlamda bireyleri birbirine bağlayan, bireysel kitle yayıncılı̆̆ına izin vererek sıradan insanların seslerini duyurmalarına aracılık etmekte ve bireyi kullanıcı olarak daha aktif ve katılımcı bir hale getirebilmektedir. Milyonlarca kitlesel yayıncı, sosyal medya platformları aracılığıla bireysel olarak haber üretebilmektedir. Geleneksel medyayla kıyaslandığında denetim sınırlı olduğu için anonim bir haber kaynağı olarak sosyal medyayı değerlendirmek mümkündür. Diğer taraftan, toplumsal olaylar ve sokak hareketleri gibi durumların yaşandığı dönemlerde yalan ve sahte haberler, sosyal medyada sıkça karşılaşılan bir durumdur. Dolayısıyla sosyal medya platformlarının yalan haberlere kaynaklık etmesi, kurumsal veya bireysel anlamda endişe konusu olmaktadır. Bu noktada dezenformasyon ve yalan haberlerin yaygınlaşması neticesinde kullanıcıların doğru enformasyona ve habere ulaşabilmeleri adına maruz kaldıkları haberleri teyit ettirmeleri ön plana çıkmaktadır. Kesitsel tarama modeli kullanılarak yapılan bu çalışmada da Türkiye'de 2020 yılı itibariyle en fazla kullanılan beş sosyal medya platformunun kullanıcılar tarafından kullanım sıklıklarının incelenmesi ve ilgili çerçevede kullanıcıların kurumsal ve bireysel güvenlerinin yanı sıra teyit davranışlarının irdelenmesi amaçlanmıştır. Öte yandan, incelemeler gerçekleştirilirken kullanıcıların bu platformları kullanım sıklıkları kümelendirilmiş ve kullanım sıklık düzeyleri açısından kurumsal ve bireysel güven ile teyit davranışının nasıl değişim gösterdiğinin anlaşılması istenmiştir. Ayrıca kullanıcıların demografik özelliklerinin, teyit davranışında nasıl bir etkiye sahip olduğu da mercek altına alınmıştır. Böyle yapılarak kullanıcıların teyit davranışı güven, kullanım sıklığı ve demografik özellikler çerçevesinde sorgulanmaya çalışılmıştır. Elde sonuçlar WhatsApp'ın kullanıcılar tarafından en çok kullanılan bir sosyal medya platformu olduğunu göstermiştir. Kurumsal güvenin bireysel güvene kıyasla daha fazla olduğu görülürken kullanıcıların teyit davranışını da sıklıkla gerçekleştirdikleri tespit edilmiştir. Sosyal medya platformlarını daha fazla sıklıkta kullanan kullanıcıların ise kurumsal ve bireysel güvene daha fazla sahip oldukları bulunmuştur. Son olarak, teyit davranışı üzerinde kurumsal ve bireysel güven ile eğitim durumunun negatif bir etkiye sahip olduğu belirlenmiştir.
\end{abstract}

\section{Anahtar Kelimeler: Sosyal Medya, Güven, Teyit, Kullanım Siklı̆ğ \\ TRUST AND VERIFICATION ON SOCIAL MEDIA: A STUDY IN THE CONTEXT OF SOCIAL MEDIA USAGE FREQUENCY}

\section{Abstract}

Social media connecting individuals globally, allow voices of the people to be heard loudly since they provided individual mass broadcasting, and as a result make it possible for individuals to be more active and participatory online users. Millions of mass broadcasters can individually produce news by means of social media platforms. Therefore, it is possible to analyze social media as an anonymous news source since the control mechanism on the social media is limited compared to traditional media. On the other hand, in times of social unrest and protest movements, disinformation and fake news on the social media are common. Thus, the source of the fake news on social media platforms is a matter of institutional or individual concern. At this point, due to the spread of misinformation and fake news, checking and verifying the news users are

\footnotetext{
* Dicle Üniversitesi, İletişim Fakültesi, Halkla İlişkiler ve Tanıtım Bölümü, E-mail: i.halilyasar@hotmail.com, ORCID ID: 0000-0002-1480-569X

** Anadolu Üniversitesi Açıköğretim Fakültesi, E-mail: zafercanugurhan@ gmail.com, ORCID ID: 0000-0003-1264-9002

*** Yazar / yazarlar, makalede araştırma ve yayın etiğine uyulduğuna ve kullanılan fikir ve sanat eserleri için telif hakları düzenlemelerine riayet edildiğine yönelik beyanda bulunmuştur.
} 
exposed to, in order to reach for the correct information and news becomes paramount. In this study, a crosssectional survey research was employed to examine the usage frequency of the most popular social media platforms in Turkey. It was aimed to investigate the users' institutional and individual trust as well as their verification behavior. Furthermore, users' usage frequency of the platforms was clustered and the effect of the users' demographic characteristics on the verification behavior was also analyzed. In this way, users' verification behavior was investigated in terms of trust, usage frequency and demographic characteristics. The results demonstrated that WhatsApp was the most used (popular) social media platform. While institutional trust was observed to be higher than individual trust, results also demonstrated that the users frequently performed verification behavior. Similarly, findings demonstrated that the users who used social media platforms more frequently than the other users, had more institutional and individual trust. Finally, it was determined that institutional and individual trust as well as educational degree had a negative effect on the verification behavior.

Keywords: Social Media, Trust, Verification, Usage Frequency

\section{Giriş}

Kullanıcı sayısı giderek artan ve günümüz insanının iletişim faaliyetlerinde olmazsa olmaz bir rutini haline gelmiş olan sosyal medyanın, kullanım amacı ve alanı giderek genişlemeye devam etmektedir. Kişilerarası iletişimden iş ve toplumsal ilişkilere kadar önemli bir konuma sahip olan sosyal medya, işletmelerin ticari faaliyetlerinden siyasal aktörlerin iletişim çabalarına kadar birçok işlevi yerine getirmektedir (Kılınç ve Arıcı, 2020, s. 211-212). İnsan hayatının sıradan bir rutini ve ayrılmaz parçası haline gelmiş olan sosyal medya, bireyin güncel konu ve olaylarla ilgili de müracaat ettiği önemli bir kaynak haline gelmiş durumdadır. Diğer bir ifadeyle sosyal medya, günümüz insanının geleneksel medyanın dışında haber edindiği ve paylaştığı önemli bir alan haline gelmiştir (Kılıç ve İspir, 2020, s. 267). Sıradan insanlar bu platformlar aracılığıla bir yandan güncel konu ve olaylarla ilgili bilgiler edinirken diğer yandan bunları yorumlayarak ve yeniden üreterek paylaşmakta, böylece bireysel anlamda birer kitle yayıncısına dönüşebilmektedir (SegadoBoj vd., 2019, s. 92). Sosyal medyanın bu niteliği onu geleneksel medyadan ve iletişim araçlarından ayıran en temel özelliği olarak değerlendirilmektedir.

Haberin üretimi ve paylaşımı açısından ele alındığında sosyal medya geleneksel medyadan oldukça farklı bir haber kaynağı durumundadır. Geleneksel medyanın hukuki düzenlemelerden meslek örgütlerine ve bunların yüzyıllara dayanan teamül ve ilkelerine sosyal medyada pek rastlanılmadığı ifade edilebilir (Lee ve Ma, 2012, s. 332). Yine geleneksel medyanın hiyerarşik yönetim biçimi ile haberin belli ilkeler ve editöryal süreçler sonucunda kitleye ulaştırılma süreci sosyal medya açısından söz konusu olan bir durum değildir. Bir diğer deyişle, kurumsal hesaplar olmakla birlikte sosyal medya milyonlarca kitlesel yayıncının bireysel olarak haber ürettiği, kontrolün hiç değilse bile son derece sinırlı olduğu anonim bir haber kaynağıdır (Chen vd., 2019, s. 3). Bu açıdan bakıldığında sosyal medya manipülasyona da son derece açıktır. Özellikle toplumsal olaylar ve sokak hareketlerinin yaşandığı dönemlerde yalan ve sahte haberler, sıkça karşılaşılan bir durumdur. Sosyal medya platformlarının bu tarz manipülatif haberlere kaynaklık etmesi, kurumsal veya bireysel anlamda endişe konusu olmaktadır (Kılıç ve İspir, 2020, s. 268). İnsanların sosyal medyadan edindikleri haberleri nasil değerlendirdikleri ise çoğu durumda belirsiz kalmaktadır. Bu açıdan bakıldığında sıradan insanların sosyal medyada karşılaştıkları yığınla bilgi ve haberi değerlendirirken bunların güvenirliğine ilişkin nasıl yaklaştıkları önemli bir soru işareti olmaktadır. Dolayısıyla giderek artan sayıda araştırma, sosyal medya haberlerinin kullanıcılar tarafindan nasıl değerlendirildiklerini, bunlara ne oranda güvendiklerini ve bu haberlerin doğruluğunu teyit etmeye ne kadar meyilli olduklarını anlamaya odaklanmaktadır (Çömlekçi ve Başol, 2019; Çömlekçi, 2019; Kutlu ve Doğan, 2020; Kılıç ve İspir, 2020). 
Küresel çapta artan bir sayıda kullanıcıların Twitter ve Facebook gibi sosyal medya uygulamalarını birer haber kaynağı olarak kullandığını gösteren çalışmalar söz konusudur (Palekar ve Sedera, 2018; Kutlu ve Doğan, 2020). Bu kullanıcilar sosyal medya platformlarını kimi zaman geleneksel medyaya alternatif, kimi zamansa onu tamamlayan bir haber kaynağı olarak kabul etmekte ve kullanmaktadır (Segado-Boj vd., 2019, s. 92). $\mathrm{Bu}$ mecraların gündem oluşturma gücü ve bu gücün sıradan insanların parmak uçlarına kadar uzaması onu önemli bir araştırma konusu yapmaktadır (Altincik, 2020, s. 10-11). Sosyal medyanın gücü ve anonim yapısı göz önüne alındığında, bireylerin sosyal medyayı kullanımı ve bu platformlardaki haber kaynaklarını nasıl değerlendirdikleri, bu ortamlardan edindikleri bilgileri ne kadar sorguladıkları ile bunların tutum ve davranışlarına ne şekilde yansıdığı araştırmacıların ilgisini çekmektedir. Tüm bunlardan hareketle bu çalışmada, sosyal medya haberlerine ilişkin kullanıcıların kurumsal ve bireysel güvenleri ile teyit davranışları, kullanıcıların sosyal medya kullanım sıklığı ve demografik özellikleri bağlamında ele alınarak incelenmiştir. Böyle yapılarak teyit davranışı yakından mercek altına alınmış ve güven, sosyal medya kullanım sıklığı ve kullanıcıların demografik özellikleri çerçevesinde anlaşılmaya çalışılmıştır. Özellikle günümüzde kullanıcıların hem haberin kaynağ 1 hem de haberin bir dağıtanı olduğu düşünüldüğünde ve sosyal medyada maruz kaldıkları haberlerin boyutu göz önünde tutulduğunda teyit davranışının yakından incelenmesi ihtiyacı ortaya çıkmaktadır (Çömlekçi, 2019; Çömlekçi ve Başol, 2019; Kutlu ve Doğan, 2020). Ayrıca "We Are Social" ile "Hotsuite" tarafindan 2020 yılı itibariyle gerçekleştirilen bir araştırmada belirlenen, Türkiye'de en fazla kullanılan 5 (beş) sosyal medya platformunun (slideshare.net, 2020) (Instagram, YouTube, Facebook, Whatsapp ve Twitter), kullanıcılar tarafından kullanım sıklıkları ile bu çerçevede kullanıcıların sosyal medyada kurumsal ve bireysel güvenlerinin yanı sıra demografik özelliklerinin de teyit davranışları üzerindeki etkileri ele alınmıştır. Öte yandan, sosyal medya kullanım sıklıkları bağlamında kullanıcılara kümelendirme yapılarak daha belirgin sonuçlara ulaşılması amaçlanmıştır. Günümüz kullanıcılarının sosyal medya kullanım dinamiğini göz önünde bulundurarak teyit davranışına yönelik bir bakış açısı sağlamaya çalışan bu çalışmanın, konuyla ilgili araştırma yapmak isteyenlere de çeşitli bulgular sunabileceği değerlendirilmektedir.

\section{Kavramsal Çerçeve}

Sosyal medya platformları bağlamında oluşan yeni tip iletişimin oluşturduğu ekosistem, farklı disiplinlerden araştırmacıların ilgisini çekmekte ve sosyal medyanın söz konusu ekosistem içerisinde çeşitli olay ve süreçler karşısında kullanıcılarına yeni alanlar açarak onları aktif ve katılımcı bireylere dönüştürdüğü savunulmaktadır (Thompson vd., 2019, s. 1-2). Gerçekten de küresel anlamda bireyleri birbirine bağlayan, bireysel kitle yayıncılığına izin vererek sıradan insanların seslerini duyurmalarına aracılık eden bu araçlar, bireyi kullanıcı olarak daha aktif ve katılımcı bir hale getirmektedir (Kim vd., 2020, s. 1). Günümüzde, ticari işletmeler ürünün tasarım aşamasından içeriğine ve fiziksel özelliklerine kadar hemen her türlü üretim aşamasını "prosumer" olarak da adlandırılan üre-tüketiciler ile birlikte yapmaya gayret etmektedir (De Laguno-Alarcon vd., 2019, s. 252). Devletler e-devlet uygulamalarına yönelirken; siyasal parti-aday ve liderler dijitalleşmenin, özellikle de sosyal medya platformlarının, karşı konulmaz cazibesine kendilerini kaptırmaktadır. Sosyal medyanın geniş bir sahada ve her türlü insan faaliyetinin merkezinde kendine bu denli büyük bir alan açmayı başarmış olması, akademik olarak da farklı açılardan incelenmesini cazip hale getirmektedir.

İlgili literatür incelendiğinde bireyin sosyal medya kullanmaktaki amaç ve motivasyonlarını inceleyen çalışmaların mevcut olduğu görülmektedir (Erdoğan vd., 2017; 
Kılıç ve İspir, 2020). Bu çalışmalar sosyal medyayı bir bütün olarak ele alırken bazıları belli bir platforma odaklanmaktadır. Farklı çalışmalar olsa da söz konusu çalışmaların iki temel çıkarıma ulaştığı iddia edilebilmektedir. Bu çıkarımlardan ilki insanoğlunun sosyal bir varlık olmasından kaynaklı olarak direkt olarak diğerleriyle iletişim kurma ihtiyacı ve ikincisi ise diğer ihtiyaçlarını karşılayabilmek için iletişime ihtiyaç duyduğu gerçeğidir (Güngör, 2016). Diğer bir ifadeyle insan olmanın bir sonucu olarak hem iletişimin kendisi temel bir ihtiyaçtır hem de diğer ihtiyaçları karşılamak için iletişime ihtiyaç vardır. Dolayısıyla kişi sosyalleşmek -ki bu da bir ihtiyaçtır- ve diğer ihtiyaçlarını karşılayabilmek için başkalarıyla iletişim kurmaya gereksinim duymaktadır (Bal, 2016). Bu ihtiyaçlardan biri de kendisini doğrudan ve/veya dolaylı olarak ilgilendiren konulardan haberdar olmaktır (Köseoğlu ve Al, 2013, s. 116-117). Zira elde ettiği bilgi ve haberler bireyin kişi, durum ve süreçler karşısında nasıl tavır takınacağını belirleyen önemli hususlardır. $\mathrm{Bu}$ bağlamda sosyal medya, geleneksel medyaya alternatif ve onu tamamlayan bir araç olarak bireyin bilgi ve haber edinme sürecinde önemli bir aktör haline gelmiş durumdadır ( $\mathrm{Su}$ vd., 2019, s. 201). Bununla birlikte güven, iletişimden pazarlamaya, sosyolojiden psikolojiye ve hatta ekonomiye kadar birçok disiplin tarafından yakın mercek altına alınan ve anlaşılmaya çalışılan önemli bir kavramdır (Cowles, 1997, s. 273). Çalışma kapsamında güven, kurumsal ve bireysel olmak üzere ikiye sınıflandırılarak ele alınmıştır. Kurumsal güven, sosyal medyada kullanıciların kurumsal medya profesyonellerinin ve gazetelerin paylaşımlarına yönelik güvenlerini temsil ederken, bireysel güven kullanıcıların yakın çevrelerinin, sosyal medyadaki diğer kullanıcıların ve sosyal medya fenomenlerinin paylaşımlarına yönelik güvenlerini ifade etmektedir. Teyit davranışı ise kullanıcıların sosyal medya üzerinden ulaştıkları bir haberi sosyal medyadaki farklı kaynaklar, internet kaynakları ve internet dışındaki kaynaklardan teyit etmelerinin yanı sıra ilgili haberin doğruluğuna/güvenirliğine yönelik araştırma yapmalarını belirtmektedir.

Sosyal medya haberlerine ilişkin güven/teyit ilişkisi üzerine yapılan birtakım çalışmalara bakıldığında bunlardan bir kısmının bilgi ve görselleri çeşitli algoritmalar vasıtasıyla karşılaştıran internet tabanlı doğrulama/teyit platformları ve bunların kullanımlarına ilişkin olduğu görülmektedir (Erkan ve Ayhan, 2018; Kavakl1, 2019). Bazı çalışmalar doğrudan kullanıcıların sosyal medya haberlerine ilişkin güvenlerine ve bunların teyit alışkanlıkları üzerine yoğunlaşmaktadır (Çömlekçi ve Başol, 2019; Kılıç ve İspir, 2020). Sonuç olarak bu çalışmalar sosyal medyanın günümüzün en sık kullanılan iletişim mecrası olmasının yanında haber edinme ve haber verme amaçlı olarak da yaygın şekilde kullanılan bir kitle iletişim aracı olduğu gerçeğini gözler önüne sermektedir. Ayrıca sosyal medya kullanıcılarının teknolojinin de artan etkisiyle birlikte güncel konu ve süreçlere dair fikir sahibi olabilmek amaciyla sosyal medyayı giderek daha fazla kullandikları belirtilmektedir (Algül ve Sütçü, 2015, s. 31). Bununla birlikte sosyal ağların kesişme mantığı ile sosyal medya kullanıcı sayısında sürekli yaşanan artışın bu platformlardan haber edinme düzeyini artırdığını da söylemek mümkündür.

Bir enformasyon kaynağı olarak bilginin durmadan akması, milyonlarca insana hızlı, kolay ve son derece düşük maliyetle ulaşma olanağı sunması gibi özellikleri sosyal medyanın çoğu zaman sert eleştirilerle ve suçlamalarla karşı karşıya kalmasına neden olabilmektedir. Nitekim geleneksel medyanın kurumsal yapısından farklı olarak çoğunlukla anonim olduğu kabul edilen sosyal medyanın manipülasyona son derece açık olduğu değerlendirilmektedir (Filibeli ve Şener, 2019, s. 492; Eren ve Aydın, 2014, s. 203). Özellikle toplumsal olaylar ve kriz ortamlarında çeşitli yapı ve kurumlar sosyal medyayı bir örgütlenme aracı olarak daha fazla kullanırken bu grupların birtakım amaçlarla manipüle edilmesi daha sık görülmektedir. Türkiye'de yaşanan Gezi Parkı olayları; Arap 
Baharı olarak adlandırılan, birçok Ortadoğu ülkesini etkileyen toplumsal hareketler ile Fransa başta olmak üzere Avrupa'yı önemli ölçüde etkileyen Sarı Yelekliler hareketi buna örnek olarak gösterilebilir. Bu bağlamda sosyal medyayla ilgili iyi veya kötü gibi kategorik bir yaklaşımda bulunmanın doğru olmayacağını belirtmek gerekmektedir (Aydemir, 2020, s. 126). Ancak, bireyler arasındaki iletişimin gerçek anlamda küreselleşmesini sağlayan, hayatımızı belli alanlarda oldukça kolaylaştıran ve değiştiren sosyal medya platformlarının birtakım ciddi riskler barındırdığını da söylemek, konuyu teşhis etmek açısından önemli görülmektedir. Bu açıdan ele alındığında geleneksel medya için öne çıkarılmış medya okuryazarlığı gibi yeni medya okuryazarlığının oldukça elzem olduğu değerlendirilmektedir (Çömlekçi ve Başol, 2019; Kutlu ve Doğan, 2020). Bu bağlamda yeni medya okuryazarlığı becerileri aracılığıyla sahte haber ve enformasyon karşısında kullanıcıların kendilerine sunulan haberleri eleştirel bir süzgeçten geçirerek gerçekliğinden kuşku duyacağı ve böylelikle yalan haber ile gerçeği ayırt edebileceği ifade edilebilir (Kutlu ve Doğan, 2020, s. 87).

Bireylerin haber edinme amaçlı olarak sosyal medya kullanımlarına bakıldığında bunu temelde iki husus konusunda yaptıkları görülmektedir (Nah vd., 2017; Yaşar, 2020). Bunlardan ilki bireyin sosyal medyayı geleneksel medyaya alternatif bir medya olarak görmesidir. Birey geleneksel medyanın kendisine sunduğu haberleri yeterli veya güvenilir kabul etmediği gibi enformasyon kaynaklarını kendi belirlemek istemektedir (De-LagunoAlarcon vd., 2019, s. 250). Bu anlamda bireyin medyadaki monopolleşmeden duyduğu rahatsızlığın etkisi söz konusu olabilmektedir. İkinci olarak birey sosyal medyayı geleneksel olana bir alternatif olarak değil de onu tamamlayıcı bir ortam olarak kabul etmektedir. Birey geleneksel medyadan birtakım haberler edinmekte, ancak bunu çeşitli nedenlerle çeşitlendirmek ve detaylandırmak istemektedir (Su vd., 2019, s. 201). Zira sosyal medyanın bir haber mecrası olarak kullanılmasında ve kabul edilmesinde geleneksel medyanın mevcut durumunun da etkili olduğu savunulmaktadır. Hem küresel çapta medya sahiplikleri hem de bölgesel ve yerel medya sahiplikleri açısından ele alındığında geleneksel medya araçlarının belli bir monopolleşme ve tekelleşmeye sahne olduğu görülmektedir. Ülkeler bazında ise belli çıkar grupları veya iş adamlarının sahipliğinde bulunan geleneksel medya araçlarının küresel çapta Batı ülkeleri ve gelişmiş ülkeler lehine olduğu değerlendirilmektedir (Kara, 2013, s. 19-21). Söz konusu ortamda sosyal medya platformlarının, hem de bireyin kendisini bir kitle yayıncısına dönüştürdüğü düşünüldügünde, birer haber edinme aracı olarak ortaya çıkması şaşırtıcı olmasa gerektir. Böylece daha anonim olduğunu düşündüğü, olay veya sürecin içinde, yakınında bulunan kişilerden bilgi edinmeyi tercih etmektedir. Burada çoğunlukla amaç, daha sansürsüz ve elekten geçirilmemiş bilgiye ulaşma isteğidir. Özellikle savaş ve çatışma bölgelerinden dolaşıma sokulan, içeriği nedeniyle geleneksel medyada yer alması mümkün olmayan görüntülerin sosyal medya platformları üzerinden servis edilmesi bu duruma örnek olabilir (Ünal, 2019, s. 42-43; Karaman ve Önder, 2017, s. 176-178).

Sosyal medya platformlarının haber amaçlı kullanımda bir diğer önemli husus bunların etkileşimli ortamlar olmasıdır. Geleneksel medyadan bir haber edinen kişi onunla ilgili yorum veya tepki göstermek istediğinde bunu çoğu zaman anlık olarak gerçekleştirememektedir. Ancak sosyal medya, kullanıcılarına edindikleri haber veya enformasyonla ilgili anlık tepki verme imkânı sunmaktadır. Üstelik yazılı, görsel veya işitsel hangi formatta olursa olsun bunu saklayarak da etkileşimin süreğen hale gelmesini sağlamaktadır (Salgado ve Bobba, 2019, s. 2258).

Yeni iletişim teknolojilerindeki gelişmelerin yanı sıra sosyal medya platformlarının da çeşitlenmesi neticesinde hızlı bir biçimde çoğalan ve neredeyse kitleselleşme düzeyine 
ulaşan dezenformasyon ve yalan haberler, kullanıcıların doğru enformasyona ve habere ulaşabilmeleri adına maruz kaldıkları haberleri teyit etmelerini ön plana çıkarmaktadır (Kutlu ve Doğan, 2020, s. 87). Geleneksel medyada haber güvenirliği olgusu, haberi sunan profesyonellerin ve kuruluşların sorumluluğuna bırakılarken, sosyal medyayla birlikte bu sorumluluk kullanıcıya geçmiştir. Özellikle sosyal medya platformlarında içerik oluşturan kaynaklarda anonim bir kimliğin söz konusu olabilmesi (Lee ve Ma, 2012, s. 338; Chen vd., 2019, s. 3), aynı içeriğin farklı zamanlarda dolaşıma konulabilmesi ve enformasyonun kullanıcılar nezdinde farklı niteliklere bürünebilmesi gibi hususlardan dolayı haber güvenirliği tartışmalı bir noktaya gelebilmektedir. Bununla birlikte, kurumsallaşmış habercilik pratikleri olmayan veya gazetecilik ilkelerini dışarıda tutarak haber yapan kişi veya kuruluşların sayıca çoğalmasından ötürü de haberlerin güvenirliği sorgulanabilmektedir (Lee ve Ma, 2012, s. 332; K1lıç ve İspir, 2020, s. 268).

Günümüzde kullanıcıların haberin ve haberde yer alan argümanların doğruluğunu teyit etmek amacıyla kullandığı, yalan haberlerle mücadele etmek adına kurulan haber doğrulama platformları (örn. Teyit.org ve Snopes.com), her geçen gün önem kazanmaktadır. $\mathrm{Bu}$ platformların temel misyonlarından biri dijital ortamdaki haberin güvenirliği konusunda kullanıcıları bilgilendirmeleridir. Böylelikle kamuoyunun doğru bir biçimde bilgilendirilmesinin sağlanması, kanaatlerin nesnel haberler ve gerçekler kapsamında oluşturulması ve dezenformasyona kullanıcıların daha az bir şekilde maruz kalmalarının sağlanması amaçlanmaktadır (Çömlekçi, 2019, s. 1553). Sonuç olarak, kullanıcıların sosyal medyada maruz kaldığı yalan haberlerden kuşku duyarak teyit davranışını gerçekleştirebileceği ve yalan haber-gerçek haber ayrımını daha net bir şekilde çizebileceği değerlendirilmektedir (Kutlu ve Doğan, 2020, s. 87).

\section{Yöntem}

$\mathrm{Bu}$ çalışmada nicel araştırma yöntemi kullanılmış ve kesitsel tarama modelinden yararlanılmıştır. Kesitsel tarama modeli, bir popülasyonun veya popülasyondan alınan örneklemin mevcut eğilimlerini, tutumlarını ve görüşlerini nicel bir şekilde, doğrudan belirlemeye olanak tanımaktadır (Creswell, 2014, s. 13). Kesitsel tarama modelinden faydalanılarak yapılan bu araştırmada, "We Are Social" ve "Hootsuite" tarafından belirlenen Türkiye'de en çok kullanılan beş sosyal medya platformunun (slideshare.net, 2020) (Instagram, YouTube, Facebook, WhatsApp ve Twitter) kullanım siklikları belirlenerek kullanıcıların kurumsal ve bireysel güvenlerinin yanı sıra teyit davranışları yakından incelenmeye çalışılmıştır.

\subsection{Amaç ve Önem}

Türkiye'de 2020 y1lı itibariyle en fazla kullanılan beş sosyal medya platformunun (Instagram, YouTube, Facebook, WhatsApp ve Twitter) kullanım sıklıklarının incelenmesi ve ilgili çerçevede kullanıcıların kurumsal ve bireysel güvenlerinin yanı sıra teyit davranışlarının irdelenmesi, bu çalışmanın esas amacıdır. Bununla birlikte, incelemeler gerçekleştirilirken kullanıcıların bu platformları kullanım sıklıkları kümelendirilmiş ve kullanım sıklık düzeyleri açısından söz konusu değişkenlerin nasıl değişim gösterdiği anlaşılmaya çalışılmıştır. Son olarak, kurumsal ve bireysel güvenin yanı sıra kullanıcıların demografik özelliklerinin, teyit davranışında nasıl bir etkiye sahip olduğu mercek altına alınmıştır. Böyle yapılarak kullanıcıların teyit davranışı güven, kullanım sıklığı ve demografik özellikler çerçevesinde sorgulanmaya çalışılmıştır.

Literatürdeki çalışmalarda sosyal medyayı genelde ya da özelde haber alma ve paylaşma amaçlı kullanma, güven ve teyit (Karaman ve Önder, 2017; Thompson vd., 2019; Erkan ve Ayhan, 2018; Kavakl1, 2019; Çömlekçi, 2019; Çömlekçi ve Başol, 2019; Ünal, 
2019; Kutlu ve Doğan, 2020; İspir ve K1lıç, 2020) bağlamında incelemeler bulunsa da yapılan bu çalışma, söz konusu olguları (güven ve teyit) diğer çalışmalardan farklı olarak kullanıcıların demografik özellikleri ve en fazla kullanılan beş sosyal medya platformunu kullanım sıklıkları özelinde mercek altına almaktadır. Özellikle kullanıcıları sosyal medya kullanım sıklık düzeyine göre kümelendirmesi ve ilgili kümeleri kullanıcıların demografik özellikleri açısından sorgulaması, bu kullanıcıların bir bakıma profilini sağlar niteliktedir. Diğer taraftan, teyit davranışını kurumsal ve bireysel güven ile demografik değişkenler bağlamında incelemesi ise bu olgunun ilişkili olduğu değişkenleri ortaya koyabilmesi bakımından önem taşımaktadır. Nitekim ilgili olgu, çalışma kapsamında ele alınan değişkenler açısından incelenerek daha belirgin bir kanıya ulaşılmaya çalışılmıştır. Bu bağlamda çalışmada, aşağıda paylaşılan araştırma soruları cevaplanmak istenmiştir:

- Kullanıcıların sosyal medya platformlarını kullanım sıklıklarının dağılımı nasıldır?

- Kullanıcilar sosyal medya platformlarını kullanım sıklıklarına göre nasıl kümelenmektedir?

- Kullanıcıların sosyal medya platformlarını kullanım sıklık kümeleri ile demografik özellikler (cinsiyet, yaş, eğitim durumu, aylık gelir ve sosyal medyada günlük harcanan zaman) arasında anlamlı bir bağ/ilişki var mıdır?

- Kullanıcıların kurumsal ve bireysel güveni ile teyit davranışı, sosyal medya platformlarını kullanım sıklık kümeleri açısından anlamlı bir biçimde farklılaşmakta mıdır?

- Kullanıcıların kurumsal ve bireysel güveni, demografik özellikler açısından anlamlı bir şekilde farklılaşmakta mıdır?

- Kullanıcıların kurumsal ve bireysel güveni ile demografik özellikleri, teyit davranış üzerinde anlamlı bir etkiye sahip midir?

\subsection{Evren ve Örneklem}

Bu araştırma Türkiye'de 2020 yılı itibariyle en fazla kullanılan beş sosyal medya platformu özelinde gerçekleştirildiğinden ötürü, çalışma evrenini ilgili platformları kullanan kullanıcılar oluşturmaktadır. Bununla birlikte, kullanıcıların tamamına ulaşabilmek pratikte mümkün olmadığından dolayı örneklemeye gidilerek olasılıklı olmayan örnekleme yöntemlerinden amaca uygun örneklemeden faydalanılmıştır. Amaca uygun örnekleme, araştırmanın amacına yönelik örnekleme seçilecek kullanıcılardan yalnızca uygun ve ulaşılabilir olanların örnekleme eklenmesidir (Başaran, 2017, s. 489). Yapılandırılan anket formu, $18 \mathrm{Kasim}$ - $30 \mathrm{Kasim} 2020$ tarihleri arasinda sosyal medya kanalları aracılığıyla dolaşıma konulmuştur. Çalışmaya gönüllü olarak katılmayı beyan eden kullanıcıların Instagram, YouTube, Facebook, WhatsApp ve Twitter platformlarının tamamına kullanmaları gerektiğinden ötürü anket üzerine bir kontrol sorusu eklenmiştir. $\mathrm{Bu}$ soruda bahsi geçen platformların hepsini kullanırım diyen kullanıcıların yanıtları, araştırma kapsamında kullanılmıştır. İlgili sorunun devamında kullanıcılara kurumsal ve bireysel güven, teyit davranışı, söz konusu platformları kullanım sıklıkları ve son olarak demografik özellikleri kapsamında sorular sorulmuştur. Toplamda 403 kullanıcıdan veri toplanmıştır.

\subsection{Veri Toplama Yöntemi ve Aracı}

Kullanılan veriler, anket tekniğiyle elde edilen verilerden oluşmaktadır. İlgili anket, Google Forms üzerine yüklenerek dolaşıma konulmuştur. Türkiye'de 2020 yılı itibariyle en çok kullanılan sosyal medya platformlarını belirleyebilmek amacıyla We Are Social ve Hootsuite tarafından yapılmış araştırma mercek altına alınmıştır. Rapor sonucuna göre 
Instagram, YouTube, Facebook, WhatsApp ve Twitter platformlarının Türkiye özelinde en fazla kullanılan sosyal medya platformlarıdır. Öte yandan, ilgili araştırmada bu platformlar dışında Facebook Messenger, Pinterest ve LinkedIn gibi platformlar bulunsa da bu çalışma kapsamında seçilen beş platform \%60'tan fazla kullanım oranına sahip olduğundan dolayı araştırmacı tarafindan kullanılmıştır. Bu bağlamda en çok kullanılan sosyal medya platformları, çalışmada beş platformla sınırlandırılmıştır. Kullanıcılardan bu platformları kullanım sıklıklarını 5'li derecelendirme seçeneği biçiminde $(1=$ Hiçbir Zaman; $5=\mathrm{Her}$ Zaman) doldurmaları rica edilmiştir.

Sosyal medyada kurumsal güven, bireysel güven ve teyit davranışını ölçümleyebilmek adına literatürde bir çalışmadan faydalanılmıştır (Çömlekçi ve Başol, 2019, s. 63). Kurumsal güven ve bireysel güven üçer maddeden oluşurken teyit davranış1 dört maddeden oluşmakta ve ölçekte toplamda 11 madde yer almaktadır. İlgili maddeler ise 5'li Likert tipi biçimindedir ( $1=$ Hiçbir Zaman; $5=$ Her Zaman $)$. Son haline getirilen anket, bir pilot çalışma gerçekleştirilerek test edilmiş ve ölçek maddelerinin anlaş1lırlığ 1 kontrol edilmek istenmiştir. Pilot çalışma kapsamında sosyal medya platformlarını kullandığ 1 ifade eden 50 kullanıcının verisine Cronbach's Alpha güvenirlik analizi uygulanmış ve güvenirlik katsayının a) kurumsal güven için $\alpha=0,88$; b) bireysel güven için $\alpha=0,75$ ve c) teyit davranışı için $\alpha=0,91$ olduğu belirlenmiştir. İncelenen maddetoplam korelasyon değerlerinin 0,40'1n üzerinde olduğu da görülmesinden dolayı kullanılan ölçeğin bu çalışma kapsamında güvenilir olduğu değerlendirilmiştir (Kalaycı, 2017; Hair vd., 2014). Daha sonra esas araştırma gerçekleştirilmiştir.

\subsection{Veri Analizi ve Kullanılan Testler}

Verilerin temizlenmesinde ve tasnif edilmesinde Microsoft Excel programı tercih edilmiştir. Verilerin analizinde IBM SPSS 25 programı kullanılmıştır. Kullanılan ölçeğe yönelik geçerlik ve güvenirlik analizleri açımlayıcı faktör analizi ve Cronbach's Alpha katsayısının kontrolü ile gerçekleştirilmiştir. Öte yandan, araştırma sorularının cevaplanabilmesi adına frekans analizi, k-ortalamalar kümeleme analizi, ki-kare bağımsızlık testi, tek yönlü varyans analizi (ANOVA), bağımsız örneklemler t-test ve çoklu regresyon istatistiklerinden faydalanılmıştır. Ulaşılan bulgular, tablolar yardımıyla raporlanarak açıklanmıştır.

\section{Bulgular}

Araştırma kapsamında 403 kişiden veri toplanmıştır. Toplanan veriye yapılan ön kontrol neticesinde üç yanıtın uygunsuz bir şekilde doldurulduğu tespit edilmiş ve veri setinden çıkartılmasına karar verilmiştir. Daha sonra tek değişkenli normallik sayıltısı, Pallant (2011) tarafindan önerilen prosedür kullanılarak kontrol edilmiş, gerekli incelemeler sonucunda etkili veriye sahip 5 gözlemin ortalamaları ve $\% 5$ kırpılmış ortalamaları değerlendirilmiştir. Bu ortalamalar arasındaki fark oldukça düşük olduğundan dolayı $(0,07-0,09)$ tek değişkenli normalliğin sağlandığı sonucuna ulaşılmıştır. Öte yandan, çok değişkenli normallik sayıltısı için Arifin (2015) tarafından önerilen yöntem kullanılmış ve ölçeklerin maddelerine yönelik Mahalanobis uzaklığ hesaplanarak 0,001 anlamlılıkta belirlenen uzaklığı aşan toplamda 11 gözlem, veri setinden çıkartılmıştır. Kalan 389 gözlem ile veri setinin hem tek değişkenli hem de çok değişkenli normalliği sağladığı sonucuna ulaşılmıştır.

\subsection{Katılımcılara İlişkin Bulgular}

Çalışma katılımcılarının \%39,8'i kadın ve \%60,2'si erkektir. Katılımcıların yaşları çoğunlukla 23-32 yaş arasında $(\% 40,6)$, daha az olarak ise 43 yaş ve üstünden $(\% 15,4)$ 
oluşmaktadır. Eğitim durumu açısından çoğunlukla lisans mezunlarının yer aldığı görülmektedir (\%47,6). Aylık gelir olarak çoğunluğun 2501-4500 TL arasında bir gelire sahip olduğu söylenebilir $(\% 29,0)$. Katılımcılar çoğunlukla sosyal medyada günlük 1-2 saat zaman geçirmektedir $(\% 40,4)$. Katılımcıların sosyal medya kullanım sıklığı bağlamında en çok sıklıkta kullanılan platform WhatsApp, en az sıklıkta kullanılan platform ise Facebook'tur. Bu bilgiler Tablo 1'de gösterilmiştir.

Tablo 1. Katılımcıların Demografik Özellikleri

\begin{tabular}{|c|c|c|c|}
\hline Değişken & Seçenekler & $\mathbf{n}$ & $\%$ \\
\hline \multirow{2}{*}{ Cinsiyet } & Kadın & 155 & 39,8 \\
\hline & Erkek & 234 & 60,2 \\
\hline \multirow{4}{*}{ Yaş } & 22 yaş ve altı & 64 & 16,5 \\
\hline & $23-32$ aras 1 & 158 & 40,6 \\
\hline & $33-42$ aras 1 & 107 & 27,5 \\
\hline & 43 yaş ve üstü & 60 & 15,4 \\
\hline \multirow{4}{*}{ Eğitim Durumu } & Lise ve alt 1 & 71 & 18,3 \\
\hline & Önlisans & 43 & 11,1 \\
\hline & Lisans & 185 & 47,6 \\
\hline & Lisansüstü & 90 & 23,1 \\
\hline \multirow{4}{*}{ Aylık Gelir } & 2500 TL ve altında & 108 & 27,8 \\
\hline & $2501-4500 \mathrm{TL}$ & 113 & 29,0 \\
\hline & $4501-6500 \mathrm{TL}$ & 92 & 23,7 \\
\hline & $6501 \mathrm{TL}$ ve üstünde & 76 & 19,5 \\
\hline \multirow{5}{*}{$\begin{array}{c}\text { Sosyal Medyada } \\
\text { Geçirilen Günlük Zaman }\end{array}$} & 1 saatten az & 58 & 14,9 \\
\hline & 1-2 saat aras 1 & 157 & 40,4 \\
\hline & 3-4 saat aras 1 & 113 & 29,0 \\
\hline & 5 saat ve üstünde & 61 & 15,7 \\
\hline & Toplam & 389 & 100,0 \\
\hline \multirow{6}{*}{$\begin{array}{c}\text { Sosyal Medya Kullanım } \\
\text { Sıklı̆gı* }\end{array}$} & Platform & $\bar{x}$ & $S S$ \\
\hline & WhatsApp & 4,27 & 1,02 \\
\hline & YouTube & 3,33 & 1,17 \\
\hline & Instagram & 3,26 & 1,42 \\
\hline & Facebook & 2,41 & 1,32 \\
\hline & Twitter & 2,43 & 1,45 \\
\hline
\end{tabular}

*1-Hiçbir Zaman; 5 - Her Zaman.

\section{İlişkin Bulgular}

3.2. Sosyal Medyada Teyit Davranışı, Kurumsal Güven ve Bireysel Güvene

Çalışmada kullanılan sosyal medyada teyit/güven ölçeğinin çalışma örnekleminde faktörlere göre nasıl bir dağılım gösterdiğini görebilmek amacıyla açımlayıcı faktör analizi (AFA) yapılmıştır (temel bileşenler analizi/varimax). Yapılan AFA sonucunda KMO değerinin 0,77 ve Barlett Küresellik Testi'nin anlamlı olduğu görülmüştür ( $x^{2}: 1371,320$; df: $45 ; p<0,001$ ). Açıklanan varyansların sırasıyla \%29,85 (teyit davranış1); $\% 25,71$ (kurumsal güven) ve \%10,08 (bireysel güven) olduğu belirlenmiştir. Öz değerler ise sırasıly 2,98; 2,57 ve 1,01 şeklindedir. Bu sonuçlar AFA'nın yorumlanması adına yeterlidir (Hair vd., 2014, s. 102). Ölçeğin faktörlerine yönelik yüklerin 0,585-0,902 arasında dağılım gösterdiği görülmektedir. Faktörlere yönelik yapılan güvenirlik analizi neticesinde Cronbach's $\alpha$ katsayısının teyit faktörü için 0,84 ; kurumsal güven faktörü için 0,82 ve bireysel güven faktörü için 0,71 olduğu tespit edilmiştir. Bu kapsamda ölçeğin güvenilir olduğu söylenebilir (Kalayc1, 2017, s. 405). Aritmetik ortalamalar incelendiğinde en yüksek ortalamaya teyit davranışı $(\bar{x}=3,59$; $\mathrm{SS}=0,89)$, sonra sirasıyla kurumsal güven $(\bar{x}=2,94 ; \mathrm{SS}=0,85)$ ve bireysel güven $(\bar{x}=2,57 ; \mathrm{SS}=0,69)$ sahiptir (Tablo 2$)$. Bu sonuç 
katılımcıların teyit davranışını çoğunlukla gerçekleştirdiklerinin altını çizerken kurumsal güvenlerinin daha fazla ve bireysel güvenlerinin daha az olduğunu gösterir niteliktedir.

Tablo 2. AFA ve Güvenirlik Analizi Sonuçları ile Betimsel İstatistikler

\begin{tabular}{|c|c|c|c|c|c|c|}
\hline Madde & $\overline{\boldsymbol{x}}$ & SS & FY & AV & ÖD & CA \\
\hline Teyit Davranışı & 3,59 & 0,89 & - & \multirow{5}{*}{29,85} & \multirow{5}{*}{2,98} & \multirow{5}{*}{0,84} \\
\hline $\begin{array}{l}\text { Sosyal medya üzerinden ulaştığım bir haberi sosyal } \\
\text { medya dışındaki internet kaynaklarından teyit ederim. }\end{array}$ & 3,85 & 0,99 & 0,887 & & & \\
\hline $\begin{array}{l}\text { Sosyal medya üzerinden ulaştığım haberi sosyal } \\
\text { medyadaki farklı kaynaklardan teyit ederim }\end{array}$ & 3,73 & 1,03 & 0,878 & & & \\
\hline $\begin{array}{l}\text { Sosyal medya üzerinden ulaştığım haberin } \\
\text { doğruluğu/güvenilirliği ile ilgili araştırma yaparım }\end{array}$ & 3,66 & 1,06 & 0,820 & & & \\
\hline $\begin{array}{l}\text { Sosyal medya üzerinden ulaştığım bir haberi internet } \\
\text { dışındaki kaynaklardan teyit ederim }\end{array}$ & 3,15 & 1,22 & 0,727 & & & \\
\hline Kurumsal Güven & 2,94 & 0,85 & - & \multirow{4}{*}{25,71} & \multirow{4}{*}{2,57} & \multirow{4}{*}{0,82} \\
\hline $\begin{array}{l}\text { Tanınmış gazetecilerin sosyal medya paylaşımlarına } \\
\text { güvenirim }\end{array}$ & 3,24 & 1,00 & 0,761 & & & \\
\hline $\begin{array}{l}\text { Basılı olarak dağıtılan gazetelerin sosyal medya } \\
\text { paylaşımlarına güvenirim }\end{array}$ & 2,81 & 0,99 & 0,902 & & & \\
\hline $\begin{array}{l}\text { İnternet gazetelerinin sosyal medya paylaşımlarına } \\
\text { güvenirim }\end{array}$ & 2,78 & 0,97 & 0,825 & & & \\
\hline Bireysel Güven & 2,57 & 0,69 & - & \multirow{4}{*}{10,08} & \multirow{4}{*}{1,01} & \multirow{4}{*}{0,71} \\
\hline $\begin{array}{l}\text { Arkadaşlarımın/tanıdıklarımın sosyal medya } \\
\text { paylaşımlarına güvenirim }\end{array}$ & 3,11 & 0,97 & 0,585 & & & \\
\hline $\begin{array}{l}\text { Kullanıcıların içerik oluşturduğu mecraların } \\
\text { paylaşımlarına güvenirim (ekşi sözlük, wikiler vb.) }\end{array}$ & 2,70 & 1,06 & 0,731 & & & \\
\hline $\begin{array}{l}\text { Sosyal medya fenomenlerinin sosyal medya } \\
\text { paylaşımlarına güvenirim }\end{array}$ & 1,90 & 0,90 & 0,738 & & & \\
\hline
\end{tabular}

\subsection{Kümeleme Analizine İlişkin Bulgular}

Sosyal medya kullanım sıklığı açısından katılımcıları gruplandırabilmek için iki adımlı bir kümeleme analizine gidilmiştir. İlk adımda, sıklıklara ilişkin kümeleme uygulanmadan önce hiyerarşik kümeleme yöntemlerinden Ward tekniği seçilerek katılımcıların kullanım sıklıkları açısından nasıl bir görüntü sergiledikleri incelenmiş ve burada sınıflandırma yapabilmek için sosyal medya platformlarına yönelik kullanım sıklığı kullanılmıştır (Hair vd., 2014, s. 442).

Sonuç olarak sosyal medya kullanım sıklığı açısından üç kümenin uygun olacağı görülmüştür. İkinci adımda hiyerarşik olmayan kümeleme yöntemi tekniklerinden kortalamalar tekniği kullanılmış ve birinci adımda görülen üç kümeli sınıflandırmanın güvenirliği test edilmiştir. Bu analiz sonucunda da hem Ward hem de k-ortalamalar tekniği için elde edilen ortalamaların birbirlerine yakın olduğu tespit edilmiştir. Dolayısıyla a) düşük sıklıkta kullananlar, b) orta sıklıkta kullananlar ve c) yüksek sıklıkta kullananlar olmak üzere üç kümeden oluşan sınıflandırma yapılmıştır. Elde edilen kümelere ilişkin betimsel bilgiler Tablo 3 'te gösterilmiştir.

Tablo 3. Sosyal Medya Kullanım Sıklığı Kümeleri

\begin{tabular}{|c|c|c|c|c|c|c|c|}
\hline \multirow{3}{*}{ Sosyal Medya Platformları } & & \multicolumn{6}{|c|}{ Kümeler } \\
\hline & & \multicolumn{2}{|c|}{$\begin{array}{c}\text { Düşük } \\
(\mathrm{n}=137 ; \% 35,2)\end{array}$} & \multicolumn{2}{|c|}{$\begin{array}{c}\text { Orta } \\
(\mathrm{n}=148 ; \% 38,0)\end{array}$} & \multicolumn{2}{|c|}{$\begin{array}{c}\text { Yüksek } \\
(\mathrm{n}=104 ; \% 26,8)\end{array}$} \\
\hline & & $\bar{x}$ & SS & $\bar{x}$ & SS & $\bar{x}$ & SS \\
\hline Instagram & & 1,78 & 0,86 & 4,09 & 0,89 & 4,03 & 0,99 \\
\hline Facebook & & 2,38 & 1,26 & 1,47 & 0,59 & 3,78 & 0,89 \\
\hline Twitter & & 1,65 & 1,08 & 2,50 & 1,40 & 3,27 & 1,42 \\
\hline YouTube & & 2,60 & 1,20 & 3,74 & 0,97 & 3,73 & 0,91 \\
\hline Whatsapp & & 4,02 & 1,01 & 4,42 & 0,93 & 4,38 & 1,08 \\
\hline & AO & 2,49 & 1,08 & 3,24 & 0,96 & 3,84 & 1,06 \\
\hline
\end{tabular}


Sosyal medyayı düşük sıklıkta kullananlar $(\% 35,2)$ en çok WhatsApp'1 kullanırken orta s1kl1kta kullananlar (\%38) WhatsApp, Instagram ve YouTube'u tercih etmektedir. Yüksek siklıkta kullananlar $(\% 26,8)$ ise sirasiyla WhatsApp, Instagram, Facebook, YouTube ve Twitter'ı kullanmaktadır.

Instagram ve YouTube sosyal medyayı orta ve yüksek sıklıkta kullananlar tarafindan daha çok tercih edilirken Facebook ve Twitter, yalnızca yüksek sıklıkta kullananlar tarafından çoğunlukla kullanılmaktadır. Bununla birlikte WhatsApp, sosyal medyayı düşük, orta ve yüksek siklıkta kullananlar fark etmeksizin benzer düzeylerde tercih edilmektedir (Tablo 3).

\section{İlişkisi \\ 3.4. Sosyal Medya Kullanım Sıklığı Kümelerinin Demografik Özelliklerle}

Sosyal medya kullanım sıklığı kümeleri ile cinsiyet, yaş, eğitim durumu, aylık gelir ve günlük sosyal medyada harcanan zaman değişkenleri arasındaki ilişkiyi/bağ inceleyebilmek amacıyla ki-kare bağımsızlık testi yapılmıştır. Analiz sonuçları Tablo 4'te paylaşılmıştır.

Tablo 4. Sosyal Medya Kullanım Sıklığı Kümelerinin Demografik Özellikler ile İlișkisi

\begin{tabular}{|c|c|c|c|c|c|c|c|c|c|}
\hline \multicolumn{2}{|c|}{ Demografik Değişkenler } & \multicolumn{6}{|c|}{ Küme } & \multirow{3}{*}{$x^{2}(\mathrm{df})$} & \multirow{3}{*}{$p$} \\
\hline \multirow{2}{*}{ Değişken } & \multirow{2}{*}{ Grup } & \multicolumn{2}{|c|}{ Düşük } & \multicolumn{2}{|c|}{ Orta } & \multicolumn{2}{|c|}{ Yüksek } & & \\
\hline & & $\mathrm{n}$ & $\%$ & $\mathrm{n}$ & $\%$ & $\mathrm{n}$ & $\%$ & & \\
\hline \multirow{3}{*}{ Cinsiyet } & Kadın & 39 & 28,5 & 82 & 55,4 & 34 & 39,8 & \multirow{3}{*}{$\begin{array}{c}24,57 \\
(2)\end{array}$} & \multirow{3}{*}{$<0,001$} \\
\hline & Erkek & 98 & 71,5 & 66 & 44,6 & 70 & 60,2 & & \\
\hline & Toplam & 137 & 100,0 & 148 & 100,0 & 104 & 100,0 & & \\
\hline \multirow{5}{*}{ Yaş } & 22 yaş ve altı & 9 & 6,6 & 42 & 28,4 & 13 & 12,4 & \multirow{5}{*}{$\begin{array}{c}88,08 \\
(6)\end{array}$} & \multirow{5}{*}{$<0,001$} \\
\hline & $23-32$ aras 1 & 32 & 23,4 & 78 & 52,7 & 48 & 46,2 & & \\
\hline & $33-42$ aras1 & 55 & 40,1 & 25 & 16,9 & 27 & 26,0 & & \\
\hline & 43 yaş ve üstü & 41 & 29,9 & 3 & 2,0 & 16 & 15,4 & & \\
\hline & Toplam & 137 & 100,0 & 148 & 100,0 & 104 & 100,0 & & \\
\hline \multirow{5}{*}{$\begin{array}{l}\text { Eğitim } \\
\text { Durumu }\end{array}$} & Lise ve altı & 36 & 26,3 & 19 & 12,8 & 16 & 15,4 & \multirow{5}{*}{$\begin{array}{c}25,27 \\
(6)\end{array}$} & \multirow{5}{*}{$<0,001$} \\
\hline & Ön lisans & 20 & 14,6 & 15 & 10,1 & 8 & 7,7 & & \\
\hline & Lisans & 46 & 33,6 & 89 & 60,2 & 50 & 48,1 & & \\
\hline & Lisansüstü & 35 & 25,5 & 25 & 16,9 & 30 & 28,8 & & \\
\hline & Toplam & 137 & 100,0 & 148 & 100,0 & 104 & 100,0 & & \\
\hline \multirow{5}{*}{ Aylık Gelir } & 2500 TL ve alt1 & 23 & 16,8 & 64 & 13,2 & 21 & 20,2 & \multirow{5}{*}{$\begin{array}{c}31,41 \\
(6)\end{array}$} & \multirow{5}{*}{$<0,001$} \\
\hline & 2501 TL-4500 TL & 44 & 32,1 & 36 & 24,3 & 33 & 31,7 & & \\
\hline & 4501 TL-6500 TL & 34 & 24,8 & 30 & 20,3 & 28 & 26,9 & & \\
\hline & 6501 TL ve üstü & 36 & 26,3 & 18 & 12,2 & 22 & 21,2 & & \\
\hline & Toplam & 137 & 100,0 & 148 & 100,0 & 104 & 100,0 & & \\
\hline Sosyal & 1 saatten az & 38 & 27,7 & 17 & 11,5 & 3 & 2,9 & \multirow{5}{*}{$\begin{array}{c}94,77 \\
(6)\end{array}$} & \multirow{5}{*}{$<0,001$} \\
\hline Medyada & 1-2 saat aras 1 & 79 & 57,7 & 49 & 33,1 & 29 & 27,9 & & \\
\hline Günlük & 3-4 saat aras1 & 20 & 14,6 & 52 & 35,1 & 41 & 39,4 & & \\
\hline Harcanan & 5 saat ve üstü & 0 & 0,0 & 30 & 20,3 & 31 & 29,8 & & \\
\hline Zaman & Toplam & 137 & 100,0 & 148 & 100,0 & 104 & 100,0 & & \\
\hline
\end{tabular}

Sosyal medya kullanım sıklığı kümeleri ile bütün demografik özellikler arasında anlamlı bir ilişki/bağ olduğu tespit edilmiştir $(p<0,001)$. Tespit edilen bu anlamlı ilişkiler/bağlar yakından incelendiğinde sosyal medya kullanım sıklığg düşük ve yüksek olanların çoğunlukla erkeklerden oluştuğu görülürken orta olanların kadınlardan oluştuğu dikkat çekmektedir $(\% 55,4)$. Bununla birlikte, kullanım sıklığı düşük olanların çoğunlukla 33-42 ile 43 yaş ve üstü yaş grubundan oluştuğu belirlenirken kullanım sıklığı orta olanların 23-32 ile 22 yaş ve altı yaş grubundan oluştuğu bulunmuştur. Kullanım sıklığı yüksek olanların çoğunlukla 23-32 ve 33-42 yaş grubundan oluştuğu görülmüştür. $\mathrm{Bu}$ bulgular, yaşça daha genç olanların orta ve yüksek kullanım sıklığına sahip olduğunu gösterirken yaşça daha yetişken olan kullanıcıların düşük kullanım sıklığına sahip olduklarının altını çizmektedir. 
Eğitim durumu değerlendirildiğinde lisans ve lisansüstü mezuniyet derecelerine sahip kullanıcıların sosyal medyayı çoğunlukla düşük, orta ve yüksek sıklıkta kullandıkları dikkat çekmektedir. Ancak, düşük sıklıkta kullanan kullanıcılarda lise ve altı mezuniyet derecesine sahip kullanıcıların nispeten daha fazla oldukları görülmektedir. Ancak, bu durum lisans mezunu kullanıcıların araştırma örnekleminde sayıca biraz daha fazla olmasından kaynaklanabilir. Gruplar kendi içinde incelendiğinde ise lise ve altı ile ön lisans ve lisansüstü mezunlarının çoğunlukla sosyal medyayı düşük sıklıkta kullandıkları söylenebilirken lisans mezunlarının ağırlıklı olarak orta ve yüksek sıklıkta sosyal medyayı kullandıkları ifade edilebilir. Aylık gelir açısından değerlendirildiğinde düşük ve yüksek sıklıkta kullananların daha çok 2500-4500 TL arası aylık gelire sahip oldukları dikkat çekerken orta sıklıkta kullananların 2500 TL ve altında gelire sahip oldukları görülmektedir. Son olarak, sosyal medyada günlük harcanan zaman mercek altına alındığında, düşük sıklıkta kullananların çoğunlukla 1 saatten az ve 1-2 saat arası zaman geçirdiği söylenebilirken orta ve yüksek sıklıkta kullananların 3-4 saat arası ile 5 saat ve üstünde zaman geçirdiği ifade edilebilir. Bu durum ise daha fazla süre geçirenlerin daha sık bir şekilde sosyal medyayı kullandıklarını gösterir niteliktedir.

\subsection{Katılımcıların sosyal medya kullanım sıklıkları açısından teyit davranışı, kurumsal güven ve bireysel güvenin incelenmesi}

Sosyal medya kullanım sıklığı açısından teyit davranış1, kurumsal güven ve bireysel güvenin anlamlı bir şekilde farklılaşıp farklılaşmadığını tespit etmek için tek yönlü varyans analizi (ANOVA) uygulanmıştır. Analiz sonucunda Levene testi, varyansların teyit davranışının yanı sıra hem kurumsal hem de bireysel güven için homojen dağıldığını gösterdiğinden dolayı analizin yorumlanması aşamasında ANOVA istatistiğinin anlamlılığı kullanılmıştır (Pallant, 2011, s. 253). Elde edilen sonuçlar Tablo 5 'te paylaşılmıştır.

Tablo 5. Sosyal Medya Kullanım Sıklığı Açısından Teyit Davranışı, Kurumsal Güven ve Bireysel Güvenin İncelenmesi

\begin{tabular}{|c|c|c|c|c|c|c|}
\hline Değişken & $\begin{array}{c}\text { Kullanım } \\
\text { Sıklığı }\end{array}$ & $\mathbf{n}$ & $\bar{x}$ & $S S$ & $\boldsymbol{F}$ & $p$ \\
\hline \multirow{3}{*}{ Teyit Davranışı } & Düşük & 137 & 3,46 & 0,96 & \multirow{3}{*}{2,506} & \multirow{3}{*}{0,083} \\
\hline & Orta & 148 & 3,70 & 0,86 & & \\
\hline & Yüksek & 104 & 3,62 & 0,82 & & \\
\hline \multirow{3}{*}{ Kurumsal Güven } & Düşük & 137 & 2,78 & 0,82 & \multirow{3}{*}{4,252} & \multirow{3}{*}{$\mathbf{0 , 0 1 5 *}$} \\
\hline & Orta & 148 & 3,04 & 0,88 & & \\
\hline & Yüksek & 104 & 3,03 & 0,81 & & \\
\hline \multirow{3}{*}{ Bireysel Güven } & Düşük & 137 & 2,42 & 0,68 & \multirow{3}{*}{5,101} & \multirow{3}{*}{$0,007 * *$} \\
\hline & Orta & 148 & 2,62 & 0,70 & & \\
\hline & Yüksek & 104 & 2,69 & 0,66 & & \\
\hline
\end{tabular}

Tablo 5'te kurumsal güven $(F=4,252 ; p<0,05)$ ve bireysel güven $(F=5,101$; $p<0,01)$ sosyal medya kullanım sıklı̆̆ı açısından anlamlı bir şekilde farklılaşmaktadır. Bununla birlikte, teyit davranışı sıklık açısından anlamlı bir şekilde farklılaşmamaktadır $(p>0,05)$. Söz konusu farklılıkların hangi sıklık grupları arasında olduğunu belirleyebilmek amacıyla Tukey testi yapılmıştır (Kalaycı, 2017, s. 15). Test sonuçlarına göre kurumsal güven bağlamında sosyal medyayı düşük sıklıkta kullananlar ile orta sıklıkta kullananlar arasında anlamlı bir farklılık vardır ( $\mathrm{md}=-0,26 ; p<0,05)$. Bireysel güven bağlamında ise düşük sıklıkta kullananlar ile orta sıklıkta $(\mathrm{md}=-0,20 ; p<0,05)$ ve yüksek sıklıkta $(\mathrm{md}=-$ $0,26 ; p<0,01)$ kullananlar arasında anlamlı bir farklılık vardır. 
Bu bulgular sosyal medyayı düşük sıklıkta kullananların orta sıklıkta kullananlara göre daha az kurumsal güvene sahip olduğunu göstermesinin yanı sıra bireysel güvene de daha az sahip olduklarının altını çizer niteliktedir. Sosyal medyayı orta ve yüksek sıklıkta kullananlar ise daha fazla bireysel güvene sahiptir. Öte yandan, sosyal medya kullanım sıklığı fark etmeksizin teyit davranışının benzer düzeylerde gerçekleştirildiği ifade edilebilir.

\subsection{Bireysel ve kurumsal güvenin demografik özellikler açısından incelenmesi}

Cinsiyet, yaş, eğitim durumu, aylık gelir ve sosyal medyada günlük harcanan zaman değişkenleri açısından kurumsal ve bireysel güvenin anlamlı bir şekilde farklılaşıp farklılaşmadığını belirleyebilmek amacıyla bağımsız örneklemler t-test ve tek yönlü varyans analizi (ANOVA) kullanılmıştır. Elde edilen sonuçlar Tablo 6'da ve Tablo 7'de paylaşılmıştır.

Tablo 6. Cinsiyet açısından teyit davranışı, kurumsal ve bireysel güvenin incelenmesi

\begin{tabular}{|c|c|c|c|c|c|c|c|}
\hline Değişken & Cinsiyet & $\mathbf{n}$ & $\bar{x}$ & $S S$ & df & $t$ & $p$ \\
\hline \multirow{2}{*}{ Kurumsal Güven } & Kadın & 155 & 3,06 & 0,84 & \multirow{2}{*}{387} & \multirow{2}{*}{2,17} & \multirow{2}{*}{$\mathbf{0 , 0 3 0}$ * } \\
\hline & Erkek & 234 & 2,87 & 0,84 & & & \\
\hline \multirow{2}{*}{ Bireysel Güven } & Kadın & 155 & 2,68 & 0,68 & \multirow{2}{*}{334,07} & \multirow{2}{*}{2,52} & \multirow{2}{*}{$0,012 *$} \\
\hline & Erkek & 234 & 2,50 & 0,69 & & & \\
\hline
\end{tabular}

(1 - Hiçbir Zaman; 5 - Her Zaman); * $p<0,05$.

Tablo 6'da görüleceği üzere cinsiyet açısından hem kurumsal güven $(t=2,17$; $\mathrm{df}=$ 387; $p<0,05)$ hem de bireysel güven $(t=2,52$; $\mathrm{df}=334,07 ; p<0,05)$ anlamlı bir biçimde farklılaşmaktadır. Dolayısıyla kadınların erkeklere göre daha fazla kurumsal ve bireysel güvene sahip olduğu söylenebilir.

Tablo 7. Demografik Değişkenler Açısından Kurumsal ve Bireysel Güvenin İncelenmesi

\begin{tabular}{|c|c|c|c|c|c|c|c|}
\hline $\begin{array}{c}\text { Demografik } \\
\text { Değişken }\end{array}$ & Değişken & Grup & $\mathbf{n}$ & $\overline{\boldsymbol{x}}$ & $S S$ & $\boldsymbol{F}$ & $p$ \\
\hline \multirow{8}{*}{ Yaş } & \multirow{4}{*}{$\begin{array}{c}\text { Kurumsal } \\
\text { Güven }\end{array}$} & 22 yaş ve altı & 64 & 3,10 & 0,86 & \multirow{4}{*}{1,19} & \multirow{4}{*}{0,31} \\
\hline & & $23-32$ aras 1 & 158 & 2,94 & 0,87 & & \\
\hline & & $33-42$ aras 1 & 107 & 2,93 & 0,83 & & \\
\hline & & 43 ve üstü & 60 & 2,82 & 0,79 & & \\
\hline & \multirow{4}{*}{$\begin{array}{l}\text { Bireysel } \\
\text { Güven }\end{array}$} & 22 yaş ve altı & 64 & 2,74 & 0,77 & \multirow{4}{*}{2,23} & \multirow{4}{*}{0,084} \\
\hline & & $23-32$ aras 1 & 158 & 2,58 & 0,73 & & \\
\hline & & $33-42$ aras 1 & 107 & 2,52 & 0,60 & & \\
\hline & & 43 ve üstü & 60 & 2,44 & 0,62 & & \\
\hline \multirow{8}{*}{ Eğitim Durumu } & \multirow{4}{*}{$\begin{array}{l}\text { Kurumsal } \\
\text { Güven }\end{array}$} & Lise ve altı & 71 & 2,71 & 0,99 & \multirow{4}{*}{3,50} & \multirow{4}{*}{$0,016 *$} \\
\hline & & Ön lisans & 43 & 3,12 & 0,88 & & \\
\hline & & Lisans & 185 & 2,92 & 0,79 & & \\
\hline & & Lisansüstü & 90 & 3,10 & 0,79 & & \\
\hline & \multirow{4}{*}{$\begin{array}{l}\text { Bireysel } \\
\text { Güven }\end{array}$} & Lise ve altı & 71 & 2,45 & 0,83 & \multirow{4}{*}{1,26} & \multirow{4}{*}{0,28} \\
\hline & & Ön lisans & 43 & 2,53 & 0,77 & & \\
\hline & & Lisans & 185 & 2,64 & 0,66 & & \\
\hline & & Lisansüstü & 90 & 2,54 & 0,59 & & \\
\hline \multirow{8}{*}{ Aylık Gelir } & & 2500 TL ve altında & 108 & 2,92 & 0,85 & \multirow{4}{*}{0,74} & \multirow{4}{*}{0,53} \\
\hline & Kurumsal & $2501-4500 \mathrm{TL}$ & 113 & 2,87 & 0,99 & & \\
\hline & Güven & $4501-6500 \mathrm{TL}$ & 92 & 2,99 & 0,70 & & \\
\hline & & 6501 TL ve üstü & 76 & 3,04 & 0,77 & & \\
\hline & \multirow{4}{*}{$\begin{array}{l}\text { Bireysel } \\
\text { Güven }\end{array}$} & 2500 TL ve altında & 108 & 2,66 & 0,77 & \multirow{4}{*}{0,91} & \multirow{4}{*}{0,43} \\
\hline & & $2501-4500 \mathrm{TL}$ & 113 & 2,55 & 0,75 & & \\
\hline & & $4501-6500 \mathrm{TL}$ & 92 & 2,53 & 0,62 & & \\
\hline & & 6501 TL ve üstü & 76 & 2,53 & 0,56 & & \\
\hline Sosyal Medyada & Kurumsal & 1 saatten az & 58 & 2,70 & 0,92 & 2,69 & $0,046 *$ \\
\hline
\end{tabular}




\begin{tabular}{cccccccc}
\hline Günlük Harcanan & Güven & 1-2 saat aras1 & 157 & 2,92 & 0,79 & & \\
Zaman & & 3-4 saat aras1 & 113 & 3,08 & 0,83 & & \\
& & 5 saat ve üstünde & 61 & 3,00 & 0,89 & & \\
\cline { 2 - 6 } & & 1 saatten az & 58 & 2,34 & 0,75 & & \\
& Bireysel & 1-2 saat arası & 157 & 2,48 & 0,63 & 6,36 & $<\mathbf{0 , 0 0 1}$ \\
Güven & 3-4 saat aras1 & 113 & 2,69 & 0,65 & 6,36 & \\
& & 5 saat ve üstünde & 61 & 2,79 & 0,76 & & \\
\hline
\end{tabular}

(1-Hiçbir Zaman; 5 - Her Zaman); $p<0,05$.

Tablo 7'de eğitim durumu açısından yalnızca kurumsal güvenin $(F=3,50 ; p<0,05)$ anlamlı bir biçimde farklılaştığı görülürken sosyal medyada günlük harcanan zaman açısından hem kurumsal güvenin $(F=2,69 ; p<0,05)$ hem de bireysel güvenin $(F=6,36$; $p<0,001)$ anlamlı bir şekilde farklılaştı̆ı dikkat çekmektedir. Bununla birlikte, eğitim durumu açısından bireysel güven, yaş ve eğitim durumu açısından kurumsal ve bireysel güven anlamlı bir biçimde farklılaşmamaktadır $(p>0,05)$. Bu bağlamda kurumsal ve bireysel güvenin yaş ile aylık gelirden bağımsız bir şekilde gerçekleştiği söylenebilirken bireysel güvenin eğitim durumundan bağımsız bir şekilde gerçekleştiği ifade edilebilir. Öte yandan, elde edilen farklılıkların hangi gruplar arasında olduğunu tespit edebilmek amacıyla işlem sonrası testlerinden Tukey testi gerçekleştirilmiştir (Kalaycı, 2017). Elde edilen sonuçlar aşağıdaki paragraflarda değişkenler özelinde detaylandırılmıştır.

Eğitim durumu açısından kurumsal güvenin hangi gruplar arasında farklılaştığını incelemek için uygulanan Tukey testi sonucunda lise ve altı mezuniyet derecesine sahip kullanıcılar ile lisansüstü mezuniyet derecesine sahip kullanıcılar arasında anlamlı bir farklılı söz konusudur ( $\mathrm{md}=-0,38 ; p<0,05)$. Lisansüstü mezuniyet derecesine sahip kullanıcılar, lise ve altı ile karşılaş̧ırııldığında daha fazla kurumsal güvene sahiptir. Sosyal medyada günlük harcanan zaman bağlamında kurumsal güvenin hangi gruplar arasında farklılaşıı̆ıııı incelemek adına yapılan Tukey testi neticesinde günlük 1 saatten az süre geçirenler ile günlük 3-4 saat süre geçirenler arasında anlamlı bir farklılık tespit edilmiştir $(\mathrm{md}=-0,37 ; p<0,05)$. Günlük $3-4$ saat süre geçiren kullanıcıların, günlük 1 saatten az süre geçirenlerle kıyaslandığında daha fazla kurumsal güvene sahip olduğu belirtilebilir. Öte yandan, bireysel güvenin hangi gruplar arasında farklılaştığını tespit edebilmek amacıyla yapılan Tukey testi sonucuna göre günlük 1 saatten az süre geçirenler ile günlük 3-4 saat ( $\mathrm{md}=-0,35 ; p<0,01)$ ve 5 saat ve üstünde ( $\mathrm{md}=-0,44 ; p<0,01)$ süre geçirenler arasında anlamlı bir farklılık bulunmuştur. Bu durum ise günlük daha çok süre geçirenler kullanıcıların daha az süre geçirenlere göre daha fazla bireysel güvene sahip olduğunu gösterir niteliktedir.

\subsection{Bireysel ve kurumsal güven ile demografik özelliklerin teyit davranışı üzerindeki etkisi}

Bireysel ve kurumsal güven ile demografik özelliklerin teyit davranışı üzerindeki etkisini tespit edebilmek amacıyla çoklu regresyon analizi kullanılmıştır. Analizden önce bireysel ve kurumsal güvenin teyit davranışıyla düşükten orta düzeye doğru istatistiksel olarak anlamlı ve negatif bir korelasyona sahip olduğu görülmüştür $(r=-0,22 ;-0,33$; $p<0,05)$. Modeldeki demografik değişkenler kukla değişken biçiminde kodlanarak analize eklenmiştir (Field, 2009, s. 254). Analiz sonuçları değerlendirilmeden önce de sayıltılar kontrol edilmiş (Durbin-Watson: 1,90; Tolerance: 0,326-0,869; VIF: 1,15-3,06) ve karşılanmıştır (Knapp, 2018, s. 314). Sonuçlar Tablo 8'de gösterilmiştir. 
Tablo 8. Bireysel ve Kurumsal Güven ile Demografik Özelliklerin Teyit Davranışı Üzerindeki Etkisi

\begin{tabular}{|c|c|c|c|}
\hline Değişken & B & $S E B$ & $\boldsymbol{\beta}$ \\
\hline Kurumsal güven & $-0,12$ & 0,06 & $-0,11 *$ \\
\hline Bireysel güven & $-0,15$ & 0,07 & $-0,14 *$ \\
\hline Cinsiyet [Erkek (1) ve Kadın (0)] & 0,09 & 0,10 & 0,05 \\
\hline Yaş 1 [ 22 yaş ve altı (1) ve 43 yaş ve üstü (0)] & $-0,07$ & 0,19 & $-0,03$ \\
\hline Yaş 2 [23-32 yaş arası (1) ve 43 yaş ve üstü (0)] & 0,14 & 0,15 & 0,08 \\
\hline Yaş 3 [33-42 yaş arası (1) ve 43 yaş ve üstü (0)] & 0,06 & 0,14 & 0,03 \\
\hline Eğitim 1 [Lise ve altı (1) ve Lisansüstü (0)] & $-0,39$ & 0,16 & $-0,17 *$ \\
\hline Ĕ̆itim 2 [Önlisans (1) ve Lisansüstü (0)] & $-0,22$ & 0,18 & $-0,08$ \\
\hline Ĕ̆itim 3 [Lisans (1) ve Lisansüstü (0)] & $-0,04$ & 0,13 & $-0,02$ \\
\hline Aylık gelir 1 [2500 TL ve altı (1) ve 6501 TL ve üstü (0)] & $-0,12$ & 0,17 & $-0,06$ \\
\hline Aylık gelir 2 [2501 TL ve 4500 TL (1) ve 6501 TL ve üstü (0)] & $-0,08$ & 0,15 & $-0,04$ \\
\hline Aylık gelir 3 [4501 TL ve 6500 TL (1) ve 6501 TL ve üstü (0)] & 0,04 & 0,14 & 0,02 \\
\hline SM geçirilen zaman 1 [1 saatten az (1) ve 5 saat ve üstü (0)] & $-0,16$ & 0,18 & $-0,06$ \\
\hline SM geçirilen zaman 2 [1-2 saat arası (1) ve 5 saat ve üstü (0)] & $-0,07$ & 0,15 & $-0,04$ \\
\hline SM geçirilen zaman 3 [3-4 saat arası (1) ve 5 saat ve üstü (0)] & $-0,12$ & 0,14 & $-0,06$ \\
\hline & 3,21 & 0,40 & \\
\hline
\end{tabular}

$R^{2}=0,10 ; p<0,01 ;{ }^{*} p<0,05 ;$ Bağımlı Değişken: Teyit Davranışı.

Regresyon modeli, teyit davranışını \%10 (F=2,501; $p<0,01)$ oranında açıklamaktadır. Değişkenlerin paylaşım davranışı üzerindeki etkilerini görebilmek amacıyla beta katsayıları incelenmiştir. Kurumsal güven, teyit davranışını negatif olarak anlamlı bir şekilde etkilerken $(B:-0,12 ; p<0,05)$, bireysel güven de benzer şekilde negatif olarak etkilemektedir $(B=-0,15 ; p<0,05)$. Dolayısıyla hem kurumsal güvenin hem de bireysel güvenin arttıkça teyit davranışının azalacağı ve azaldıkça artacağı ifade edilebilir. Diğer taraftan, eğitim düzeyi lise ve altı olan katılımcılar, eğitim düzeyi lisansüstü olan katılımcılara göre daha az teyit davranışı gerçekleştirmektedir $(B=-0,39 ; p<0,05)$. Cinsiyet, kullanım sıklığ 1 , yaş, aylık gelir ve sosyal medyada geçirilen zamanın ise teyit davranışı üzerinde anlamlı bir etkisi yoktur $(p>0,05)$. Bir diğer deyişle, teyit davranışının bu değişkenlerden bağımsız bir şekilde kullanıcılar tarafından gerçekleştirildiği ifade edilebilir.

\section{Sonuç ve Tartışma}

Çalışma, 2020 yılı itibariyle Türkiye'de en fazla kullanılan beş sosyal medya platformunu merkeze alarak kullanıcıların yaklaşımlarına odaklanmaktadır. Bu amaçla kullanıcıların ilgili sosyal medya platformlarını kullanma sıklıkları, kaynağa ilişkin kurumsal ve bireysel güvenleri ile demografik özellikleri çerçevesinde teyit davranışları incelenmek istenmiştir. Kullanıcıların söz konusu platformları kullanım sıklıkları kümelendirilerek kullanım sıklık düzeyleri bağlamında ilgili değişkenlerin nasıl değişim gösterdiği anlaşılmaya çalışılmıştır. Öte yandan, kurumsal güven ve bireysel güvenin yanı sıra kullanıcıların demografik özellikleri ile bahsi geçen beş platformu kullanım sıklıkları açısından teyit davranışında nasıl bir etkiye sahip olduğu incelenmiştir. Sonuç olarak kullanıcıların teyit davranışı a) kullanım sıklığı, b) güven ve c) demografik özellikler çerçevesinde mercek altına alınmıştır.

Çalışma sonuçları sosyal medya platformlarının insan hayatına ve faaliyetlerinde bulunduğu merkezi konumu doğrular niteliktedir. Zira sonuçlar sosyal medyada harcanan zamanının azımsanamayacak düzeyde olduğunu göstermektedir. Katılımcıların ilgili platformları kullanma sıklıkları açısından ele alındığında en sık kullanılan platformun WhatsApp olduğu görülmektedir. Bu platformun anlık iletişimi sürekli ve siradan hale getirmeyi başarması dolayısıyla yaygın bir kullanım alanına eriştiği değerlendirilmektedir. Bilindiği üzere WhatsApp, sesli ve görüntülü görüşme, konum, metin, anında fotoğraf ve 
video paylaşım gibi özellikleri içinde barındırması, haber ve bilgi edinme açısından kullanıcılarına kolaylık tanımaktadır (Ünal, 2019, s. 34).

Çalışma kapsamında ele alınan bir diğer konu katılımcıların sosyal medyadan edindikleri bilgi ve haberleri teyit etme davranışıdır. Bu bağlamda sonuçlar, kullanıcıların genel anlamda teyit davranışı ortalamalarının yüksek olduğunu göstermektedir. Kullanıcıların sosyal medyadan edindikleri bilgi veya haberleri daha çok hangi kanallardan teyit etmeye çalıştıklarına bakıldığında ise sosyal medya dışındaki diğer internet kaynaklarının öne çıktığı görülmektedir. İnternet dışındaki kaynaklar ise teyit amaçlı kullanılmakla birlikte görece daha düşük düzeydedir. Teyit etme davranışının yüksek olması kullanıcıların sosyal medyadan yayılan haberlerin gerçekliği ve inandırıcılığı konusunda şüpheci olduklarını işaret eder nitelikte değerlendirilebilir. Nitekim günümüzde yeni iletişim teknolojilerinin sağlamış olduğu imkânlar çerçevesinde habere hızlı ve kolay bir biçimde ulaşmak söz konusu olmuş ve bunun bir sonucu olarak gazetelerin tirajları azalmış ve bireyler haberlere ulaşmak için gazetelerin web sayfalarını, çevrimiçi haber sitelerini ve de sosyal medyayı tercih eder hale gelmiştir (Kutlu ve Doğan, 2020, s. 97). Sosyal medya sahte haberlerin hızlı bir şekilde yayılmasına yol açabildiği gibi, bu haberlerin sosyal medya kullanıcıları tarafından hızlı biçimde teyit edilmesine de olanak sağlamıştır (Bode ve Vraga, 2015, s. 620-621). Bu noktada internet üzerinden haber doğrulama platformlarına erişim konusuna dikkat çekilmektedir. Bilindiği üzere Teyit.org ve Snopes.com gibi internet tabanlı doğrulama platformları sosyal medyada yer alan yalan haberlerin doğrulanması amacıyla hizmet sunan platformlarıdır. Kullanıcılar bu platformlar aracılığıyla sosyal medyada karşılaştıkları haberleri teyit edebilmektedir (Çömlekçi, 2019).

Kullanıcıların sosyal medyadan edindikleri bilgi ve haberlerin kaynağına ilişkin güven bağlamında yapılan analizlerde kurumsal güvenin bireysel güvenle kıyaslandığında daha fazla yüksek olduğu görülmüştür. Katılımcılar kurumsal güven çerçevesinde daha çok tanınmış gazetecilerin sosyal medya paylaşımlarına güven duyarlarken internet gazetecilerinin sosyal medya paylaşımlarına ilişkin güvenin görece daha düşük olduğu görülmüştür. Bireysel güven açısından bakıldığında katılımcıların arkadaşlarının/tanıdıklarının sosyal medya paylaşımlarına güvenin yüksek olduğu sosyal medya fenomenlerinin paylaşımlarına ise daha az güvendikleri tespit edilmiştir. Literatürdeki çalışmalarda da benzer sonuçlar elde edilmesine ilaveten geleneksel medyada ve sosyal medyada yer alan haberlere ilişkin güvene yönelik yapılan karşılaştırmalarda sosyal medyada güvenin daha düşük olmasına karşın geleneksel medyadaki güvenin daha yüksek olduğu görülmüştür (Kutlu ve Doğan, 2020, s. 98). Özellikle kurumsal anlamda tanınmış gazetecilerin paylaşımlarına yönelik güvenin yüksek olmasında kurumsal güven etkisinden bahsedilebilir. Ancak, kurumsallaşmış habercilik pratiklerinden yoksun veya gazetecilik ilkelerini dışarıda tutarak haber yapan kişi veya kuruluşların da varlığı göz önünde bulundurulduğunda internet gazetecilerine yönelik güven konusunda kullanıcıların tereddüt yaşadığı düşünülmektedir (Kılıç ve İspir, 2020, s. 268). Ayrıca, sosyal medya fenomenlerinin markalarla iş birliği modelinden hareket ederek reklam iletişimi gibi faaliyetlerle paylaşım yapmaları, kullanıcıların fenomenlerin paylaşımlarına yönelik güvenlerinin düşük olmasını açıklayabilir (Müller ve Christandl, 2019, s. 48; Youn ve Shin, 2020, s. 217). Nitekim yapılan çalışmalarda sosyal medya fenomenlerinin markalarla çeşitli anlaşmalar sonucunda ürün/hizmet reklamlarını yaptıkları sponsorlu içeriklerde abartı gibi unsurları kullanarak kullanıcıları yönlendirdikleri tespit edilmiş durumdadır (Djafarova ve Rushworth, 2017, s. 4; Djafarova ve Trofimenko, 2019, s. 1439-1440). Sonuç olarak kullanıcılar, fenomenlerden ziyade arkadaşlarının ve yakın çevrelerinin paylaşımlarına daha çok güvenebilmektedir. 
Sosyal medya kullanım sıklığı kümeleri açısından değerlendirildiğinde WhatsApp'ın bütün sıklık kümeleri açısından mutlaka kullanılan bir platform olarak ön plana çıkması, incelemeye değerdir. İçeriğin kişiselleştirilmesi kapsamında diğer platformlarla kıyaslandığında WhatsApp, daha hedefli bir ilişki biçimini ön plana çıkarmaktadır. Bu bakımdan bilgi ve haber paylaşımı çerçevesinde kullanıcılar ve gruplar arasında WhatsApp'ın daha fazla kullanıldığı değerlendirilmektedir (Karaman ve Önder, 2017; Göncü, 2018; Ünal, 2019). Öte yandan, platformun kendi mantı̆̆1 çerçevesinde yaklaşıldığında Twitter'ın daha çok haber amaçlı kullanıldığı bilindiğinden dolayı (Bayraktutan vd., 2014), diğer sosyal medya platformlarına kıyasla Twitter, kullanıcılar tarafından haber dışında daha az sıklıkta kullanılmaktadır. Sosyal medya kullanım sıklığı yaş ilişkisine bakıldığında yaşın kullanım sıklığıyla ters orantılı olduğu görülmektedir. Diğer bir ifadeyle sosyal medya kullanım sıklığı arttıkça katılımcıların yaşları düşmektedir. Yaşça daha yetişkin olan kullanıcıların sosyal medyayı daha az sıklıkta kullandığı görülse de bu kullanıcıların sosyal medyanın bilgi ve haber almada sağlamış olduğu olanaklar ile zaman ve mekân açısından dijital ortamın sunduğu imkânlar dâhilinde toplumsal olaylara duyarlılıklarının yüksek olması, yakın akraba ve eski arkadaşlara ulaşma gibi motivasyonlarla sosyal medyayı kullandıkları bilinmektedir (Şentürk, 2017, s. 191). Öte yandan, genç kullanıcıların sosyal medyayı daha çok bilgi edinme, sosyalleşme, ifşa, etkileşim, kullanım kolaylığı, eğlence, dışa dönüklük, değerlendirme ve öğrenin kolaylığı gibi motivasyonlarla kullandıkları değerlendirilmektedir (Erdoğan vd., 2017, s. 396). Bu bağlamda, sosyal medyada geçirilen sürenin arttıkça ilgili platformlarda maruz kalınan bilgi ve haberlerin yoğunluğunun artabileceği düşünülmektedir.

Sosyal medyayı düşük sıklıkta kullanan katılımcıların, orta sıklıkta kullananlarla kıyaslandığında kurumsal güvenlerinin daha yüksek olduğu görülmüştür. Sosyal medyayı orta ve yüksek sıklıkta kullanan kullanıcılarda ise düşük sıklıktakilere kıyasla kaynağa ilişkin bireysel güvenin daha yüksek olduğu belirlenmiştir. $\mathrm{Bu}$ bulgu literatürdeki çalışmalarla örtüşmektedir. Hermida ve diğerleri (2012) tarafından yapılan çalışmada genç sosyal medya kullanıcılarının profesyonel haberciler tarafından sosyal medyada paylaşılan haberlere daha fazla güvenme eğiliminde olduğu tespit edilmiştir. Bu çalışmada da orta ve yüksek sıklıkta kullanan kullanıcıların daha çok gençlerden oluştuğu göz önünde tutulduğunda literatürdeki ilgili bulguyu desteklemektedir. Yapılan bir diğer çalışmada kurumsal gazetelerin haberleri ile sosyal medya haberleri karşılaştırılmış ve kurumsal gazetelerin haberlerine yönelik güvenin daha fazla olduğu görülmüştür (Balc1 ve Bekiroğlu, 2014, s. 207-208). Başka bir çalışmada sosyal medyada profesyonellerce üretilen haberlere ve tanınmış gazetecilerin paylaşımlarına yönelik kullanıcı güveninin daha yüksek olduğu bulunmuştur (Çömlekçi ve Başol, 2019, s. 70). Bu çalışma ise orta ve yüksek sıklıkta sosyal medyayı kullanan kullanıcıların kurumsal gazetelerde haber yapan gazetecilere yönelik güvenlerinin yüksek olduğunu gösterir niteliktedir.

Teyit davranışı üzerinde hem kurumsal güvenin hem de bireysel güvenin negatif bir etkisi olduğu tespit edilmiştir. Kurumsal ve bireysel güvenin arttığında teyit davranışının azalacağı, kurumsal ve bireysel güvenin azaldıkça teyit davranışının artacağı ifade edilebilir. Bu bakımdan kullanıcı güveni, teyit davranışı hususunda belirleyici bir etkendir. Sosyal medyada güven üzerine yapılan çalışmalarda, kullanıcıların içerik paylaşan tanınmış bir içerik oluşturucuya yönelik güveninin, söz konusu içerik oluşturucunun paylaştığ1 içeriğe yönelik güvenini etkilediği görülmüştür. Bir diğer deyişle, içerik oluşturan kullanıcı kendine yönelik duyulan güveni, paylaştığı içeriğe de yansitabilmektedir (Reinikainen vd., 2020, s. 291). Dolayisiyla kurumsal ve bireysel güveni artan kullanıcı, ilgili kişilerin sosyal medyada paylaştığı haberlere daha çok 
güvenebilmekte ve onları daha az teyit etme ihtiyac1 hissedebilmektedir. Demografik özellikler açısından yalnızca eğitim durumunun teyit davranışı üzerinde bir etkiye sahip olduğu belirlenmiştir. Lise ve altı eğitim düzeyine sahip kullanıcıların sosyal medya haberlerini teyit etmeye lisansüstü eğitim düzeyine sahip kullanıcılara göre daha az meyilli oldukları dikkat çekmiştir. Diğer bir ifadeyle, eğitim düzeyi yükseldikçe sosyal medyadan edinilen bilgiyi veya bir haberi teyit etme oranı yükselmekte ve düştükçe azalmaktadır. Cinsiyet, yaş, aylık gelir ve sosyal medyada harcanan günlük zamanın ise teyit davranışı üzerinde bir etkisinin olmadığı görülmüştür. $\mathrm{Bu}$ bağlamda teyit davranışının ilgili özelliklerden bağımsız bir şekilde gerçekleştiği söylenebilir. Eğitim düzeyinin yükselmesi bilgi teyidine yönelik ihtiyacı da beraberinde getirmektedir. Özellikle eğitim düzeyi, kullanıcının çevresiyle olan iletişiminde yakın çevre ve dünyada olan olayları idrak ve analiz etmesinde önemli bir husustur (Kılıç ve İspir, 2020, s. 281-282). Zira, sahte haberlerin ve yanlış bilgilerin sürekli olarak dolaşıma konulması, sosyal medyayı dezenformasyon ortamına dönüştürebilmektedir (Aydın, 2020). Eğitim düzeyi yükselen kullanıcı çevresinde ve dünyada olup biten olaylar hakkında bilgilenmek amaciyla sosyal medya platformlarında daha fazla vakit geçirebilmekte ve ileriye dönük bir şekilde bilgi arama ve teyit etme konusunda bu platformlarda bulunan, kaynağı belli olmayan yalan haberlerin ve bilgilerin azaltılmasında önemli bir role sahip olmaktadır (Kılıç ve İspir, 2020, s. 282). Sonuç olarak eğitim düzeyi artan kullanıcı sosyal medyada maruz kaldığı haberleri teyit etmeye daha meyillidir.

\section{Sınırlılıklar ve İleri Çalışmalar}

Bu çalışma 2020 yılı itibariyle Türkiye'de en fazla kullanılan beş sosyal medya platformunu kullanan 389 katılımcının verisiyle gerçekleştirilmiş ve sosyal medya, söz konusu beş platformla sınırlandırılmıştır. Dolayısıyla, sadece bu beş platformun yanı sıra diğer sosyal medya platformlarının da güven ve teyit açısından incelenmesi, bu çalışmaya yönelik bulguların genellenebilirliğine katkı sağlayacaktır. Bununla birlikte, araştırmanın farklı zamanlarda daha fazla örneklem sayısıyla tekrarlanması, literatüre daha tutarlı bulgular sunabilecektir. İleride yapılacak çalışmalarda teyit davranışının altında yatan motivasyonlar, sosyal medya kullanım sıklığı açısından araştırılabilir. Hangi sıklık grubundaki bireylerin hangi temel motivasyonlarla teyit davranışını gerçekleştirdiği tespit edilebilir. Böylelikle teyit davranışı motivasyonlarıyla güven ilişkisi daha yakından mercek altına alınabilir.

\section{Kaynakça}

Algül, A. ve Sütçü, C. S. (2015). Değisșen haber algısı: Kullanıcılar sosyal medyada haberleri nasıl değerlendiriyorlar. Global Media Journal TR Edition, 6(11), 18-34.

Altincik, H. (2020). Halkla ilişkiler perspektifinden medya ve yerel yönetim ilişkisi. İstanbul: Kriter Yayınevi.

Arifin, W. N. (2015). The graphical assessment of multivariate normality using SPSS. Education in Medicine Journal, 7(2), 71-75.

Aydemir, A. (2020). Toplumsal hareketler ve sosyal medya. İstanbul: Kriter Yayınevi.

Aydın, A. F. (2020). Post-truth dönemde sosyal medyada dezenformasyon: Covid-19 (yeni koronavirüs) pandemi süreci. Asya Studies-Academic Social Studies/Akademik Sosyal Araştırmalar, 12(4), 76-90.

Bal, H. (2016). İletişim sosyolojisi sosyal iletişim, kitle iletişimi, elektronik iletişim. Bursa: Sentez Yayıncilik. 
Balcı, Ş. ve Bekiroğlu, O. (2014). Medyanın kritik ve süreğen dönemeci: Üniversite öğrencilerinin gözünden medya haberlerinin güvenilirliği. Selçuk Üniversitesi Illetişim Fakültesi Akademik Dergisi, 8(2), 192-217.

Başaran, Y. K. (2017). Sosyal bilimlerde örnekleme kuramı. Akademik Sosyal Araştırmalar Dergisi, 47(5), 480-495.

Bayraktutan, G., Binark, M., Çomu, T., Doğu, B., İslamoğlu, G. ve Aydemir, A. (2014). Siyasal iletişim sürecinde sosyal medya ve Türkiye'de 2011 genel seçimlerinde Twitter kullanımı. Bilig, 68, 59-96.

Bode, L. and Vraga, E. K. (2015). In related news, that was wrong: The correction of misinformation through related stories functionality in social media. Journal of Communication, 65(4), 619-638.

Chen, X., Sun, M., Wu, D. and Song, X. Y. (2019). Information-sharing behavior on WeChat moments: the role of anonymity, familiarity, and intrinsic motivation. Frontiers in Psychology, 10, 1-15.

Cowles, D. L. (1997). The role of trust in customer relationships: asking the right questions. Management Decision, 35(4), 273-282.

Creswell, J. W. (2014). Educational research: Planning, conducting, and evaluating quantitative and qualitative research. New York: Pearson.

Çömlekçi, M. F. (2019). Sosyal medyada dezenformasyon ve haber doğrulama platformlarının pratikleri. Gümüşhane Üniversitesi İletişim Fakültesi Elektronik Dergisi, 7, 1549-1563.

Çömlekçi, M. F. ve Başol, O. (2019). Sosyal medya haberlerine güven ve kullanıcı teyit alışkanlıkları üzerine bir inceleme. Galatasaray Üniversitesi İletişim Dergisi, 30, 55-57.

De-Laguno-Alarcon, C., Sierra-Herrezuelo, P. and Rojas-de-Gracia, M. (2019). Resultsoriented influencer marketing manual for the tourism industry. K. Mezghani ve W. Aloulou (Eds.), Business transformations in the era of digitalization. (p. 249-275). Hershey: IGI Global.

Digital 2020 Turkey, (2020). https://www.slideshare.net/DataReportal/digital-2020turkey-january-2020-v01, Erişim Tarihi: 13.09.2020.

Djafarova, E. and Trofimenko, O. (2019). "Instafamous" - credibility and self-presentation of micro-celebrities on social media. Information, Communication \& Society, 22(10), $1432-1446$.

Djafarova, E. and Rushworth, C. (2017). Exploring the credibility of online celebrities' Instagram profiles in influencing the purchase decisions of young female users. Computers in Human Behavior, 68, 1-7.

Erdoğan, B. Z., Özata, F. Z., Doğan, S. ve Şaşmaz, A. (2017). Konum tabanlı mobil Swarm uygulaması üzerinden paylaşım motivasyonlarının incelenmesi. Tüketici ve Tüketim Araştırmaları Dergisi, 9(2), 379-400.

Eren, V. ve Aydın, A. (2014). Sosyal medyanın kamuoyu oluşturmadaki rolü ve muhtemel riskler. KMÜ Sosyal ve Ekonomik Araştırmalar Dergisi, 16(1), 197-205.

Erkan, G. ve Ayhan, M. (2018). Siyasal iletişimde dezenformasyon ve sosyal medya: Bir doğrulama platformu olarak Teyit.org. Akdeniz Illetişim Dergisi, 29, 202-223. 
Field, A. (2009). Discovering statistics using IBM SPSS statistics. UK: Sage.

Filibeli T. E. ve Şener, O. (2019). Manipüle edilmiş enformasyonel bir vitrin ve popülist bir enformasyon alanı olarak Twitter. Hacettepe Üniversitesi Iletişim Fakültesi Kültürel Çalışmalar Dergisi, 6(2), 492-515.

Göncü, S. (2018). Kullanımlar ve doyumlar yaklaşımı çerçevesinde y kuşağının WhatsApp kullanımı üzerine bir inceleme. TRT Akademi, 6(3), 592-612.

Güngör, N. (2016). İletişim kuramlar yaklaşımlar. Ankara: Siyasal Kitabevi.

Hair, J. F., Black, W. C., Babin, B. J. and Anderson, R. E. (2014). Multivariate data analysis. New York: Pearson.

Hermida, A., Fletcher, F., Korell, D. and Logan, D. (2012). Share, like, recommend: Decoding the social media news consumer. Journalism Studies, 13(5-6), 815-824.

Kalaycı, Ş. (2017). SPSS uygulamalı çok değişkenli istatistik teknikleri. Ankara: Dinamik Akademi Yayın Dağıtım.

Kara, T. (2013). Sosyal medya endüstrisi. İstanbul: Beta Yayıncılık.

Karaman, M. ve Önder, M. (2017). Yurttaş gazeteciliğinin ana akım medyaya etkisi: Whatsapp ihbar hatları örneği. Erciyes İletişim Dergisi, 5(2), 164-180.

Kavaklı, N. (2019). Yalan haberle mücadele ve internet teyit/doğrulama platformları. Erciyes Iletişim Dergisi, 6(1), 663-682.

Kılıç, D. ve İspir, N. B. (2020). Sosyal medya haber içeriklerine güven ve kullanıcı motivasyonları. E-Kurgu Anadolu Üniversitesi İletişim Bilimleri Fakültesi Uluslararası Hakemli Dergisi, 28(1), 266-285.

Kılınç, O. ve Arıcı, A. (2020). Sosyal ağlarda büyük veri: Teknoloji markaları üzerine bir araștırma. Connectist: Istanbul University Journal of Communication Sciences, 58, 201-240.

Kim, J., Namkoong, K. and Chen, J. (2020). Predictors of online news-sharing intention in the U.S and South Korea: An application of the theory of reasoned action. Communication Studies, 71(2), 315-331.

Knapp, H. (2018). Intermediate statistics using. SPSS. USA: Sage.

Köseoğlu, Y. ve Al, H. (2014). Bir siyasal propaganda aracı olarak sosyal medya. Akademik Incelemeler Dergisi, 8(3), 103-125.

Kutlu, A. ve Doğan, E. (2020). Kesin bilgi, yayalım: hakikat sonrası çağda yalan haberlere ilişkin y kuşağının tutum ve davranışları. Akdeniz Üniversitesi İletişim Fakültesi Dergisi, 34, 83-101.

Lee, C. S. and Ma, L. (2012). News sharing in social media: the effect of gratifications and prior experience. Computers in Human Behavior, 28(2), 331-339.

Müller, J. and Christandl, F. (2019). Content is king - but who is the king of kings? The effect of content marketing, sponsored content \& user-generated content on brand responses. Computers in Human Behavior, 96, 46-55.

Nah, S., Namkoong, K., Record, R. and Van Stee, S. K. (2017). Citizen journalism practice increases civic participation. Newspaper Research Journal, 38(1), 62-78. 
Palekar, S. and Sedera, D. (2018). Influence of social broadcasting networks on news consumption. Australasian Journal of Information Systems, 22, 1-29.

Pallant, J. (2011). SPSS survival manual: A step-by-step guide to data analysis using SPSS. New York: Open University Press.

Reinikainen, H., Munnukka, J., Maity, D. and Luoma-aho, V. (2020). 'You really are a great big sister' - parasocial relationships, credibility, and the moderating role of audience comments in influencer marketing. Journal of Marketing Management, 36(3-4), 279-298.

Salgado, S. and Bobba, G. (2019). News on events and social media: A comparative analysis of Facebook users' reactions. Journalism Studies, 20(15), 2258-2276.

Segado-Boj, F., Diaz-Campo, J. and Redondo, R. Q. (2019). Influence of the "news finds me" perception on news sharing and news consumption on social media. Communication Today, 10 (2), 90-104.

Su. M., Liu, J. and McLeod, D. M. (2019). Pathways to news sharing: issue frame perceptions and the likelihood of sharing. Computers in Human Behavior, 91, 201210.

Şentürk, Ş. D. (2017). 60 Yaş üstü bireylerin sosyal ağlarda yer alma motivasyonları: Facebook örneği. E-Journal of New Media/Yeni Medya Elektronik Dergi, 1(2), 183-195.

Thompson, N., Wang, X. and Daya, P. (2019). Determinants of news sharing behavior on social media. Journal of Computer Information Systems, 60(6), 593-601.

Ünal, R. (2019). Anaakım medyada kullanıcı türevli içeriğin izini sürmek: NTV ve Star TV Whatsapp ihbar hatları üzerine bir inceleme. Mersin Üniversitesi Sosyal Bilimler Enstitüsü Dergisi, 2(2), 34-43.

Yaşar, İ. H. (2020). Sosyal medya ve siyaset. Ankara: Orion Akademi.

Youn, S. and Wonsun Shin, W. (2020). Adolescents' responses to social media newsfeed advertising: the interplay of persuasion knowledge, benefit-risk assessment, and ad scepticism in explaining information disclosure. International Journal of Advertising, 39(2), 213-231. 